\title{
Manevi Danışmanlıkta Duanın Bir Destekleme Metodu Olarak Kullanımı
}

\begin{abstract}
Selma BAŞ*
Öz: Manevi danışmanlıkta kullanılan destekleme metotlarından biri, belki de en sık kullanılanı, "dua"dır. Dua geleneksel olarak zamandan, dilden ve mekândan bağımsız olarak bize Tanrı'yla (Mutlak, Yüce Varlık, Kutsal vb.) iletişim kurabilme yetisi kazandıran bir araç olarak kabul edilir. Bu nedenle manevi danışmanların sıklıkla kullandığı bir destekleme metodudur. Ancak aynı dinî gelenek içinde dahi farklı inanç ve uygulamaların olabileceği gerçeği, duayı bir destekleme metodu olarak kullanacak manevi danışmanların farkında olmalarını gerektiren bazı hususları ortaya çıkarır. Bu amaçla makalemizde duanın ne anlamlara geldiği, türleri, psikolojik işleyiş mekanizması, sağlığı nasıl etkilediğini açıklayan teoriler ile manevi danışmanlıkta duayı kullanırken dikkat edilmesi gereken hususlar ve farkında olunması gereken riskler konu edinilmiştir.
\end{abstract}

Anahtar Kelimeler: Dua, Destekleme Metodu, Manevi Danışmanlık, Dua Çeşitleri, Sağlık, Dua-Sağlık İlişkisi Teorileri

\section{The Use of Prayer as a Method of Intervention in Chaplaincy}

Abstract: Prayer is a way of intervention, probably the most frequently used approach, in chaplaincy. Traditionally, prayer is a means of communication with God (The Absolute, the Supreme Being, Divine etc.) boundless from time, space and spoken language. For that reason it is used as a way of intervention among the practitioners of pastoral care. However, since the different practices and the understandings of prayers exist even within the same belief system, using prayer as an intervention requires practitioners to be aware of some issues. For this purpose, this paper studies the following subjects: The meanings and different forms of prayer, its psychological functions, theories on the effects of prayer on health; and the things to take care of and the pitfalls of using the prayers in chaplaincy.

Keywords: Prayer, Intervention, Chaplaincy, Forms of Prayer, Health, Theories of Prayer-Health Relations

* Marmara Üniversitesi İlahiyat Fakültesi, Din Psikolojisi Bilim Dalı Doktora Öğrencisi.

E-Posta: selmabas@marun.edu.tr 
"Dua çok güçlü bir araçtır ve kullanırken dikkat gerektirir" 1

\section{Giriş}

Dinî ve manevi inançların, bireyin tedavi planı oluşturulurken alınacak kararlarda etkili olması ve hastalık ve sakatlıkla başa çıkmalarında bireylere yardımcı olması sebebiyle ${ }^{2}$ sağlık hizmeti sunan uzmanların, kişilerin bu ihtiyaçlarını göz önünde bulundurması beklenen bir davranıştır. Ülkemizde de hastanelerde yatarak tedavi gören hastalara din ve moral hizmetleri sunulması ilk defa Sağlık Bakanlığı bütçesi görüşmelerinde 1994 yılı sonlarında gündeme gelmiş ve komisyonun bu önerisi Bakanlık tarafından Diyanet İşleri Başkanlığı’nın da desteği ile 19.01.1995 tarihinde uygulamaya konmuştur. Uygulamaya katılacak din görevlilerinin uyması gereken kurallar kendilerine tebliğ edilmiş ancak düzenlemede "dua edilmesi" ifadesi yerine "Kur’ân okunması" ifadesinin yer alması daha sonra bazı tartışmaların ortaya çıkmasına neden olmuştur. Hastaların bir arada bulunduğu koğuşlarda bir hasta için Kurân okunması, bir diğer hasta ya da hasta yakınının içinde bulunduğu özel ruh hali ve Kurân okunması ile ölümün özdeşleştirilmesi gibi genel bir kanı neticesinde morallerinin bozulmasına ve yanlış anlamalara yol açmıştır. Gelen şikayetler üzerine Sağlık Bakanlığ 7.6.1996 tarihinde uygulamayı sonlandırma kararı almıştır. ${ }^{3}$

Ülkemizde yaşanan bu olumsuz duruma rağmen, yapılan araşırmalar bize sağlık hizmetleri bağlamında manevi danışmanların, din görevlilerinin ve hatta sağlık çalışanlarının en çok kullandığı manevi bakım destekleme metodunun dua etmek olduğunu göstermektedir. ${ }^{4}$ Dahası dua dinî geleneklerde kullanılan manevi bir uygulama olmakla kalmayıp, dindarlığın ve maneviyatın hassas bir göstergesi olarak kabul edilir. ${ }^{5}$ Duanın manevi bakım hizmeti sunarken temel destekleme metotlarından biri olması nedeniyle ne olduğu, türleri, psikolojik işleyiş mekanizması ve duanın manevi bakımda bir destek aracı olarak ne zaman ve nasıl kullanılması gerektiği makalemizin ana temalarını oluşturacaktır.

\section{Dua nedir?}

Dilimize Arapça'dan geçen dua kelimesi "çağırmak, seslenmek, istemek, yardım talep etmek” anlamındaki "da’vet” ve "da’va” kelimeleri gibi masdar olup, "küçükten büyüğe,

1 Kirkwood, Pastoral Care in Hospitals, s. XI (K. D. Richmond'dan naklen).

2 Cohen-v.dgr., "Prayer as Therapy", s. 41.

3 Ayrıntılı bilgi için bk. Altaş, "Hastanelerde Dinî Danışmanlık Hizmetleri”, s. 599-659.

4 VandeCreek, "Mahalle Papazlarının Hastanede Yatan Kilise Üyelerine Yönelik Dua Vaizliği”, s. 153-167; Silton-v. dgr., "Pray Tell: The Who, What, Why, and How of Prayer Across Multiple Faiths", s. 41-52; Handzo-v.dgr., "What Do Chaplains Really Do? I., s. 20-38; Handzo-v.dgr., "What Do Chaplains Really Do? II." s. 39-56; Gibbons-v.dgr., "Describing What Chaplains Do in Hospitals", s. 201-207; Ross-v.dgr., "Prayer and Self-Reported Health Among Cancer Survivors in the United States, National Health Interview Survey, 2002”, s. 931-938.

5 Spring, Encountering God, s. 16. 
aşağıdan yukarıya vaki olan talep ve niyaz" anlamında isim olarak da kullanılır. Ayrıca Allah’a sunulacak talepleri sözlü veya yazılı olarak dile getiren metinlere de dua denilir. İslâm literatüründe ise Allah’n yüceliği karşısında kulun aczini itiraf etmesi, sevgi ve tazim duyguları içinde lütuf ve yardımını dilemesi anlamına gelir. 6 "Allah’a yalvarma, yakarma, O’ndan bir şey isteme, işlediğimiz herhangi bir suçtan dolayı bağışlanmayı arzu etme" demektir. $^{7}$

Sherwin İbranicede duanın "le-hitpallel" kelimesiyle ifade edildiğini ve "kişinin kendi kendinî incelemesi” yani iç gözlem yapması anlamına geldiğini aktarır. Dua içgözlem yapmak için bir araçtır ve kişi ile yüce bir güç arasında bir köprü vazifesi görür. ${ }^{8}$ Dua, varlığın anlamını insana sunan sorulara cevap vermek suretiyle benlik arayışı sürecinde insana katkıda bulunur. ${ }^{9}$ Din psikolojisinin kurucularından William James’e (ö.1910) göre dua "ilahi kabul edilen bir güçle her türlü içsel paylaşımdır." ${ }^{10}$ James "insanların belirsiz bir evrenle uzlaşmak, başa çımak için dua etmek zorunda olduklarını” düşünür. ${ }^{11}$

Her ne kadar dua tarihi, kişisel, mezhebi ve kültürel değişkenler tarafından şekillendirilse de, bu değiş̧kenler içinde bir tür "öteki” ile bağlantılı olma duygusu mevcuttur. Dolayısıyla duanın tanımını "öteki” kavramının nasıl anlaşıldığı belirler. ${ }^{12}$ Bir doktor olan ve duanın insan sağlığı üzerindeki etkisini araştıran Dossey ${ }^{13}$ duanın "Mutlak ile iletişim" olduğunu savunur. Tanrı yerine Mutlak ifadesinin tanıma kapsayıcılık kazandırdığını, tanımın dinî toleransı onaylayarak, insanları kendileri için "iletişimin" ne olduğunu, "mutlağın” ne veya kim olabileceğini tanımlamaya davet ettiğini ileri sürer. Duayı "Tanrı ile konuşma" şeklinde tanımlayan bir diğer çalışmada Winslow-Winslow ${ }^{14}$, dua tanımında kullanılan "Tanrı" kavramının "Yüce Güç, Mutlak, Kutsal Kaynak, Kutsal, Büyük Ruh ya da duanın yöneltildiği varlığı adlandıracak başka şekillerle” genişletilmesinden yanadırlar. Çünkü bazı kişiler için Tanrı kavramı rahatsız edici olabilir.

Taylor, duanın "Tanrı ile karşılaşma” olduğunu düşünür. Dua mevcut anda bulunmak, sadece Tanrı’nın mevcudiyetinde yaşamaktır. Ona göre kişi, birinin gülümsemesinden memnuniyet duyarken, pencereden gökyüzünü seyrederken ya da mevcut bedensel fonksiyonları için şükran duygusunu belirtirken Tanrı ile karşılaşabilir. ${ }^{15}$

6 Cilac1, "Dua", DİA, IX, 529.

7 Aydemir, "Tedavide Duanın Yeri”, s. 7.

8 Hollywell-Walker, "Private Prayer as a Suitable Intervention for Hospitalised Patients", s. 638.

9 Sayın, “Tasavvuf ve Psikoloji Açısından Duanın Terapik Etkileri”, s. 426.

10 Breslin-Lewis, "Theoretical Models of the Nature of Prayer and Health", s. 10; Levine, "Prayer as Coping", s. 82.

11 Levine, "Prayer as Coping", s. 80.

12 Gubi, "An Exploration of the Use Of Christian Prayer in Mainstream Counselling", s. 426-427.

13 Dossey, "Prayer, Medicine, and Science: The New Dialogue", s. 10.

14 Winslow -Winslow, "Examining the Ethics of Praying With Patients", s. 170-177.

15 Taylor, "Prayer's Clinical Issues and Implications”, s. 183-184. 
Pınar ${ }^{16}$ duanın insana Allah'la doğrudan doğruya ilişki kurma, O’na hitap etme imkanı verdiğini savunur. Dilin temel ilkesinin varlıksal eşitliğin sağlanması olduğunu, ancak duanın bu ilkeyi bozarak kişiye ruhun ve zihnin olağanüstü bir durumda Allah'la gerçekleştirdiği konuşmaya imkan sağlayan bir araç olduğunu belirtir.

Kirkpatrick, bağlanma kuramından yola çıkarak Tanrı̉nın ilerleyen yaşlarda kişinin bağlanma nesnesi olan annenin yerini aldığını savunur. Bu nedenle dua etmek "kişinin varl1ğında kendini güvende hissettiği bir bağlanma nesnesine yakınlık arayışı" olarak görülebilir. ${ }^{17}$

Murray ${ }^{18}$ ise duayı "yalvarma ve istediğini elde etme meselesi olarak değil kendimizi kendi manevi doğamızla aynı eksene getirme" anlamında kullanır. Bu da Tanrı’nın hakkımızda planladığı şeyi daha kolay kabul etmemizi sağlar. Cappsée göre dua, kelimenin tam anlamıyla, "en mükemmel dinî tecrübedir." 19

Bütün hakiki dualar öncelikle bir yanıttır. Dua bütün bir kişinin yanıtıdır -beden ve kalp, biliş, irade ve duygulanım. Dua bir insan yanıtı ve insan eylemidir ve bu sıfatla insan tecrübesinin bütün iniş çıkışlarına açıktır. Yanıt olan dua temelde bağlamsaldır. Dua durumlara yanıt olarak ortaya çıkar. Endişe, üstün yeteneklilik, sınırlılık, ihtiyaç durumlarıyla karşılaşıldığında insanın dua ile karşılık vermesi oldukça yaygındır. ${ }^{20}$ Dua ihtiyacın ifadeye dönüşmüş şeklidir ve beraberinde ihtiyacın giderileceğine dair ümit taşır. ${ }^{21}$

Cohen ve arkadaşları ${ }^{22}$ çalışmalarında teistlerin duada "Tanrı ile karşılaştıkları" için dua ettiklerini savunurlar. Duada temel ve en önemli şey yaratıcı ve hayat verici ile kişisel bir ilişkiye girme yolu olmasıdır. İnsanlar dua ederken kendileri ile Tanrı arasındaki tür farklıl1ğını kabul ederek, kendi varlıklarınn kaynağı ve varacağı yer olarak gördükleri Bir’in önüne gelmişlerdir. Kamil bilgisi ve sevgisi kendi yakarışlarını önceleyen ve bu yakarışları olası kılan Tanrı'ya gelirler. Her ne kadar kendilerini ihtiyaç sahibi olarak sunsalar da amaçları sadece bu taleplerini O'na iletmek değildir. Teist olarak en temel ihtiyaçlarını yani "Tanrı ihtiyaçlarını" karşılamak için gelirler. Taleplerini de işte bu ilişki bağlamında takdim ederler. ${ }^{23}$ Tanrı ile Tanrı olarak ilişkide olmak, Tanrı̉nın kişinin kendi kontrolünde olduğunu varsayması değil, aksine kendisini Tanrı’ya teslim etmek ve kendisini Tanrı’nın idaresinde güvende görmek anlamına gelir. ${ }^{24}$

Bütün bu tanımlardan yola çıkarak temelde duanın bireyin Mutlak, Tanrı, Yüce Güç, Büyük Ruh, Kutsal Kaynak, İlahi ya da kutsal kabul edilenle iletişim kurması; kendi kendinî

\footnotetext{
16 Pınar, Duanın Ruh Sağlı̆̆ı Üzerindeki Etkileri, s. 13.

17 Levine, "Prayer as Coping", s. 84.

18 Stoner, "Say a Little Prayer", s. 55.

19 Capps, "İstek Duası (Petitionary Prayer) Psikolojisi”, s. 159.

20 Morgan, "Pastoral Counselling and Petitionary Praying", s. 150.

21 Pınar, Duanın Ruh Sağlı̆̆ı Üzerindeki Etkileri, s. 75.

22 Cohen-v.dgr., "Prayer as Therapy", s. 42.

23 Cohen-v.dgr., "Prayer as Therapy”, s. 42.

24 Cohen-v.dgr., "Prayer as Therapy", s. 43.
} 
incelemesi ya da iç gözlem yapması; öteki ile bağlantılı olması; kendinî kendi manevi doğası ile aynı eksene taşıması; Tanrı ile karşılaşma; kendinî varlığında güvende hissettiği bağlanma nesnesiyle yakınlık arayışı; kişinin Tanrı ihtiyacını karşılaması; en kamil dinî tecrübe; insanın içinde bulunduğu bağlama verdiği bilişsel, duyuşsal ve iradi bir yanıt olduğu yolunda farklı farklı şekillerde yorumlandığını söyleyebiliriz.

\section{Duanın Türleri}

Dua, araştırmacının perspektifine göre farklı farklı kavramsallaştırılmıştır. Breslin-Lewis, ${ }^{25}$ Allport'un (ö.1967) "kişilerin sayısınca dua çeşidi olduğunu" belirttiğini naklederler. Breslin-Lewis çalışmalarında yazarların bakış açılarına göre farklı isimlerle adlandırdıkları dua çeşitlerini şöyle belirtirler: Şükran duası, tapınma duası, tefekkür duası, ritüel dua, itiraf duası, bağlılık ifade eden (commitment) dua, yakarış duası, boyun eğme (teslimiyet) duası, nesnel ve öznel dualar, karşılıklı konuşma şeklinde yapılan dua, istek duası, övgü duası, uyum duası, tetkik etme duası, ağlama duası, terk etme duası, acı çekme, radikal ifade duası, huzur duası, sakramental ${ }^{26}$ dua, dinleme, şefaat, af dileme duası ve matem duası. Biz bu çalışmamızda Poloma ve Gallup’un ${ }^{27}$ dua çeşitlerini araştırdıkları çalışmalarında elde ettikleri verilerden eriştikleri dört katlı sınıflandırmayı esas alacağız.

\section{1. İstek (Petitonary) Duası}

$\mathrm{Bu}$ dua çeşidi, adeta bütün dua çeşitlerinin prototipi gibidir. Çocukların dualarının ilk tipik örneği bu türdedir. Bu dua, bireyin kendisi, ailesi ve arkadaşlarının ciddi bir ihtiyacı olduğunda, onların mutluluğunu engelleyecek bir tehdit unsuru veya onlarla birlikte kendi gücünü aşan problemler ortaya çıktığında, Tanrı'dan yardım talep etmek için yapılır. Bu talepler ihtiyaçlardan ve hastalıklardan kaynaklanan sorunlar olabileceği gibi bireyi rahatsız eden başka sorunlarda olabilmektedir. ${ }^{28}$ İstek duası ile diğer dualar arasındaki temel fark, istek duasında duanın iletişimsel karakterine daha fazla vurgu yapılırken diğer dua türlerinde (övgü, tefekkür, itiraf gibi) bizimle Tanrı arasında gerçekleşen iletişim olarak yorumlanmasidir. ${ }^{29}$

İstek duaları hastalık durumlarında kullanıldığında iradeyi iyileşmek üzere harekete geçirmek suretiyle tedavi edici etki yaratabilir. Hal böyle iken William James bu dua çeşidinîn ferdin “Tanrı'nın iradesini kendi iradesi yönünde değiştirme niyeti” taşıdığı için problemli olduğu görüşündedir. Bu nedenle etkisi yalnızca dua edenle sınırlıdır. ${ }^{30}$ Strang

25 Breslin-Lewis, “Theoretical Models of the Nature of Prayer and Health", s. 10-11.

26 Sakramental: Dini törenle, ayinlerle ilgili olan.

27 Williamson, "Review of Varieties of Prayer: A Survey Report", s. 203-204.

28 Argyle, "İbadet ve Dua", s. 331.

29 Capps, "İstek Duası (Petitionary Prayer) Psikolojisi”, s. 161.

30 Capps, “İstek Duası (Petitionary Prayer) Psikolojisi”, s. 160-161. 
ise yakarış dualarının isteklerden daha kapsayıcı olduğunu, bu tür duaların taleplerin yanı sıra “Tanrı’nın yardımına duyulan ihtiyacın kabulünü” de ifade ettiğini belirtir. O duada kullanılan dilin ilgili duyguları aktive etmek suretiyle ya da zorlukla ve sıkıntıyla yüzleşen kişi bunlarla başa çıkma gücünün kendisinde mevcut olduğuna inandığı için faydalı olduğunu savunur. Kişi bu tarz dualarda netice ne olursa olsun Tanrı’nın irade ettiği şeyi izleyeceğine dair yemin ifade eden teslimiyet cümlesi de kullanır. Bu nedenle netice ne olursa olsun dua dili, kişi Tanrı’nın iradesine teslim olmayı kabul ettiği ve bu yolla bir görevi yerine getirmiş olduğu için öz saygıyı geliştirir. ${ }^{31}$

İstek duası başlığı altında incelenmekle birlikte bir yönüyle bu dualardan farklılaşan şefaat (intercessory prayer) dualarından da bahsetmemiz yerinde olacaktır. Dossey ${ }^{32}$ şefaat (intercessory) kelimesinin Latince inter "arasinda" ve cedere "gitmek" kelimelerinden geldiğini belirtir. Bu nedenle şefaat duası aracılık yapmak anlamına gelir. Başka birisi adına aracılık yapmak ya da başka birisinin durumu için yalvarma çabasıdır. Şefaat duasında kendisi için dua edilen kişi genellikle dua eden kişiden uzak olduğu için "uzaktan" dua (distant prayer) olarak da adlandırılır. Şefaat duasında harici bir kişi dua edilenin bilgisi dahilinde ya da ondan habersiz, onayı olsun ya da olmasin dua eder. ${ }^{33}$

Strang ${ }^{34}$ şefaat duasını “Tanrı ile insan arasında başka birinin adına, Tanrı’nın o kişinin iyiliğine hareket edeceği ümidiyle yapılan konuşma” şeklinde tanımladıktan sonra daha seküler bir yaklaşımla şefaat duasını "yüce bir güce (bu varlığı belirlemeksizin) belirli bir talebe göre hareket etmesi için yalvarma eylemi” olarak betimler. Bununla birlikte Hıristiyan geleneğinde şefaat duası olağanüstü bir müdahale için bir başkası adına Tanrı’ya yalvarmak olarak anlaşılır. Ayrıca şefaat duası "Tanrı ile konuşma olarak görülmekle birlikte endişelerimizi, enerjimizi ve belirli bir kişiye duyduğumuz sevgiyi içtenlikle takdim etmemiz nedeniyle bir "sunuş" ve "aktif bir dua"dır.

Başkası adına yapılan şefaat dualarını da içeren istek duaları en çok müracaat edilen dua formudur. Genellikle günlük konuşma diliyle yapılır. Birey kendisine göre kutsal olan güce taleplerini, içinde bulunduğu durumu samimi bir dille ifade eder. Bu dua formu kutsal varlığa bireysel talepleri ilettiği gibi, kişinin Tanrı’nın yardımına muhtaç olduğunu da gösterir. Yani varlıksal olarak kişinin kendi konumunu ve gücünü kabullendiği, yüce olana teslim olduğu bir tutumun ifadesidir. Duanın bu özelliği, kişiye teslimiyet duygusu kazandırarak karşılaşılan zorluklarla başa çıkmasında yardımcı olur.

\footnotetext{
31 Levine, "Prayer as Coping", s. 90; Dini başa çıkma konusunda daha ayrıntılı bir çalışma için bk. Ali Ayten, Tanrıya Sığınmak Dini Başa Çıkma Üzerine Psiko-Sosyal Bir Araștırma.

32 Dossey, "Prayer, Medicine, and Science: The New Dialogue", s. 10.

33 Hollywell, "Private Prayer as a Suitable Intervention for Hospitalized Patients", s. 638.

34 Strang, "Is Intercessory Prayer in Modern Nursing a Valid Practice?", s. 93.
} 


\subsection{Tefekkür (Meditative) Duası}

Meditasyon tarzında yapılan dua, başvurulan dua çeşitleri arasında en az kullanılan dua türüdür. ${ }^{35} \mathrm{Bu}$ dua şeklinde dua edenin “Tanrı’nın konuşmasını bekleyen bir dinleyici pozisyonunu aldığını” ${ }^{36}$ dolayısı ile tefekkür duasının "Tanrı’ya sessizce yoğunlaşmak" 37 olduğunu söyleyebiliriz. Bazı yazarlar meditasyon ile tefekkür duasını farklı farklı kavramlaştırırken bazıları ise ikisi arasında her hangi bir fark görmezler. Breslin-Lewis, ${ }^{38}$ Foster’n meditasyonel dua ile tefekkür duasının iki ayrı şey olduğunu, ilkinin kutsal metinlerin anlamı üzerinde tefekkür etmeyi, tefekkür duasının ise "Tanrı’nın sessizliği” konusunda farkındalık geliştirmeyi gerektirdiğini ileri sürdüğünü; Finney ve Malony’nin tefekkür duasında dikkati toplamak için belirli teknikler kullanıldığını, bu nedenle bu dua şeklinin de bir tür meditasyon olarak kabul edilmesi gerektiğini savunduğunu; Helminiak’n ise Hıristiyan geleneğinde tefekkür olarak adlandırılan şeyle bugün meditasyon olarak adlandırılan şeyin aynı şey olduğunu söylediğini belirtirler.

Geleneksel olarak ibadette veya dinî tecrübede yapılan meditasyonun amacı Tanrı’yla ilişkiye girip onun huzurunda hazır bulunmaktır. Meditasyon, her ne kadar farklı dinî inançlar içinde farklı tecrübeler gibi görünse de temel amacı dinî tecrübeler yaşamaktır. Bu meditasyonların hepsi bireyde, değişik bilinç durumlarına yol açtığı için bir rahatlama meydana getirir. ${ }^{39}$

Dua bireyin duygusal halini ve bilinç durumunu değiştirir. Bazı dua şekilleri ile meditasyona eşlik eden zihni durum betimlemeleri arasında benzerlik mevcuttur. Düzenli dua etme zihni bir duruma ve rahatlama duygusuna neden olur. Dolayısıyla düzenli dua eden kişi meditasyonun sağladığı olumlu etkilerden yararlanır. Düzenli dua etmenin faydalı olması kısmen meditasyonel durumla ve kısmen de problemi Tanrı'ya havale etmeyi izleyen gerilimin azalması ve sıkıntının giderilmesine şartlanmışlıkla özdeşleştirilen psikolojik değişimlerle açıklanabilir. ${ }^{40}$

Alanyazında meditasyon ile tefekkür duası arasında benzerlik ve farklılıklar tartışılmakla birlikte, her ikisinin de bireye sağladığı ruhsal ve fiziksel faydalar arasında ortak yönler tespit edilmiştir. Tefekkür duası daha az müracaat edilen bir dua türüdür. Ancak çalışmamızın ilerleyen bölümlerinde de işaret edileceği üzere manevi danışmanın bu dua türü hakkında da farkındalık geliştirmesi gerekir. Çünkü bazı hastaların fiziksel ve ruhsal durumları bu dua türünden daha fazla faydalanmasına elverişli olabilir.

\footnotetext{
35 Argyle, "İbadet ve Dua", s. 332.

36 Winslow-Winslow, "Examining the Ethics of Praying With Patients", s. 171.

37 Spring, Encountering God, s. 18.

38 Breslin-Lewis, “Theoretical Models of the Nature of Prayer and Health", s. 10.

39 Argyle, "İbadet ve Dua", s. 332.

40 Levine, "Prayer as Coping", s. 90.
} 


\subsection{Dinî Pratik Olarak (Ritualistic) Dua}

Wullf dinî pratik olarak yapılan duaların, genellikle halk arasında bilinen ve mensubu olduğu dinîn din görevlisi tarafından bir kitaptan veya ezbere okunarak yapılan dualar olduğunu belirtir. Bu dua türünde, temelde standart dinî uygulama formüllerini içeren ve bu formüllerle desteklenmiş istek veya bağllık anlamı taşıyan kalıplaşmış ifadeler yer alır. $\mathrm{Bu}$ tarz dualar, genellikle monoton ve belirli bir ses tonuyla okunur. Ayrıca duanın içeriğine bakıldığında, yeteri derecede manevi bir duygu hissetmeksizin, kalıplaşmış ifadelerin yinelendiği görülür. ${ }^{41}$

$\mathrm{Bu}$ tarz dualar bireysel yapılmakla birlikte çoğunlukla grup halinde yapılır. Ortak bir duaya ait kelimelerin ibadet esnasında ferdî olarak ya da grupla yinelenmesi bireyin dinî grupla ve bu grubun değerleriyle özdeşleşmesini sağlar. ${ }^{42}$ Başkalarının varlığında bildik, belirli duaları yinelemek ayrılık duygusunu azaltır. Yaşarken ortaya çıkan bir problem soyutlanma duygusunu uyandırdığında ya da sosyal kimliği parçaladığında -"bu korkunç olayı yaşayan tek kişi benim" ya da "ben dışlanmayı hak ettim"- grupla dua etmek bireyde oluşan soyutlanmışlık duygusunu azaltır. ${ }^{43}$

Levine ${ }^{44}$ duayı başa çıkma mekanizması olarak ele aldığı ve psikolojik tahlilini yaptığı çalışmasında grupla dua etmenin öz saygıyı geliştirmeye pek çok bakımdan katkı sağladığını belirtir ve bunları şu şekilde irdeler:

1. Grupla dua ederken herkes aynı kelimeleri tekrar eder. Ortak bir ritüele katılmak psikolojik toplum olma duygusunu pekiştirir. Başkaları ile paylaşılan inançlar kişinin inançlarının doğruluğu kanaatini geliștirir.

2. Cemaat, destek grubu olarak algılanır. Cemaat üyeleri duygusal gıda ve birbirlerine daha somut yardım sağlarlar. Katılım soyutlanmanın ve yalnızlığın panzehiridir. Bireyin huzur bulmasını sağlar. Cemaatin üyesi başkalarından yardım istediğinde kendisine hoşnutlukla yardım edileceğine inanır (algısal destek).

3. Edilen dualar geleneksel ise ve düzenli bir şekilde tekrarlanıyor ise bu durumda üyeler bir tarihi olan ve süreklilik arzeden bir gruba katıldıklarını hissederler. Bu ise katılımcıya zaman ve mekânda bir aşkınlık duygusu ve kendinden daha büyük ve güçlü bir şeyin parçası olduğu hissini verir.

4. Bildik bir ritüel stresli hayat olayları ile baş edebilmek için sosyal olarak onaylanmış bir eylem sunar. Bunun en güzel örneği, sevilen bir kişinin ölümü üzerine ölüyü onurlandırmak için düzenlenen dua merasimidir. Dua ve ritüel herkese mevcut durumda yapılması

41 Argyle, "İbadet ve Dua”, s. 332-333.

42 Levine, "Prayer as Coping", s. 91.

43 Levine, "Prayer as Coping", s. 91-92.

44 Levine, "Prayer as Coping", s. 92. 
gereken doğru şeyin ne olduğunu anlatır, dolayısıyla ne yapılması gerektiği ile alakalı belirsizliği ortadan kaldırır.

Her ne kadar bu dua formu kalıplaşmış ifadelerin bireysel olarak ya da grupla yinelenmesini içerse de sosyal destek duygusu yaratması, tarihi bir geçmişi olan ve süreklilik arzeden bir yapının parçası olmanın kişide meydana getirdiği aidiyet duygusu ve kriz dönemlerinde (ölüm, hastalık gibi) yaşanan belirsizlik (ne yapacağını bilememe) hallerinde sosyal grubun onayladığı davranış formları sunması yönüyle bireye faydası dokunan bir dua formudur. Ayrıca çalışmamızın ilerleyen bölümlerinde Neville Kirkwood'un çalışmasına atıfla "nefes duası"ndan bahsedilecektir. Kirkwood, özellikle durumu çok ağır olan hastalara ritüel duaları andıran, Tanrı'nın meşhur bir ismi ile bireyin o anki ihtiyacını ifade eden bir kelime yan yana getirilmek suretiyle dua formu oluşturduğunu söyler. İstenildiği kadar yinelenebilen bu dua, kişiye tavsiye edilir. Bir manevi danışmanın her dinde mevcut bu tarz ritüel duaların ve bunların nasıl kullanılabileceğinin farkında olması gerekir.

\subsection{Konuşma Diline Ait (Conversational) Dua}

Konuşma şeklindeki dua "Tanrı ile yapılan gayri resmi konuşma" ${ }^{45}$ veya "kişinin, Tanrı’ya içinden geldiği şekilde, kendi kelimeleriyle hitap ettiğì" 46 dua şeklidir. Diğer dua çeşitleri arasında en yaygın kullanılan dua türünün bu olduğunu söyleyebiliriz. ${ }^{47}$ Ayrıca duanın tanımı konusunda değindiğimiz üzere genel dua tanımlarının çoğu duanın bu boyutu üzerinde yoğunlaşmaktadır. Argyle, Poloma ve Pendleton’ın çalışmalarına atıfla "bireylerin kendi kelimeleriyle Tanrı ile konuşarak, ondan kendilerine ait herhangi bir konuda karar verebilmeleri için rehberlik etmesini isteme tarzında" bir dua türü tespit ettiklerini aktarır. Genel olarak bakıldığında bu dua tarzında birey, Tanrı ile diğer şahıslarla sıradan bir dille konuştuğu gibi konuşmakta ve O’na karşı çok samimi davranmaktadır. ${ }^{48}$

\section{Duanın Psikolojik İşleyiş Mekanizması}

Dua etmek James'in ifadesiyle "konuşmak"tır. Konuşma eylemi ise doğası gereği bir muhatap gerektirir. Duada bu muhatap içsel bir Tanrı (Yüce Güç, Mutlak, Kutsal, vb.) tasavvurudur. ${ }^{49}$ İçsel bu konuşma ise kişinin psikolojisinde bazı neticeler doğurur. Spilka, kişilerin dua ederken genellikle ilk olarak Tanrı'nın gücünü ve ferdin Tanrı’nın yardımına olan ihtiyacını kabul ettiğini belirtir. Duanın bir hedefi elde etme amacına yönelik ikinci evresinde ise, bir hedefi olan her konuşmada ya da bütün psikoterapilerde olduğu gibi,

45 Spring, Encountering God, s. 18.

46 Ümit Horozcu "conversational prayer" ya da "colloquial prayer" şeklinde ifade edilen bu dua türünü, "samimi hitap duası" diye tercüme etmiştir (Horozcu, Din Psikolojisi Acısından Dunyevi İstek Duaları, s. 64).

47 Argyle, "İbadet ve Dua", s. 333.

48 Argyle, "İbadet ve Dua”, s. 333.

49 Aktaran Levine, "Prayer as Coping”, s. 83. 
kelimeler ve cümleler günlük dilde bir anlam ifade edecek şekilde zamansal bir sıralama ile dile getirilir. Kişinin kendi kendine sesli ya da sessiz bir şekilde konuşması kişiyi sıkıntı halini karakterize eden tam oluşmamış duygu ve düşünceleri anlamlandırmaya zorlar ${ }^{50}$. Capps ${ }^{51}$ ilk dönem psikologlarının dönemin popüler telkin (suggestion) teorisinden çok etkilendikleri için istek duasını "kendi kendine telkinin (autho-suggestion) bir şekli" olarak gördüklerini belirtir. Yani görünüşte Tanrı’ya yöneltilmiş dualar gerçekte kişinin kendi kendisiyle yaptığı monologlardır. İstek duası kişinin kendi kişisel ilgilerini ifade etmesine imkan tanır ve gerçek bir iletişim meydana gelmese bile, kişide tipik bir duygusal boşalma/ dışavurum ve/veya insan iradesinin harekete geçirilmesi neticelerini doğurur. Gubi ${ }^{52}$ danışmanlıkta duanın kullanımını değerlendirdiği makalesinde, duanın "duyguları yeniden formüle etmenin bir yolu ve duyguları boşaltmada bir katarsis" rolü görebilecek bir unsur olduğunu belirtir.

Psikoterapi hastası, özellikle de onaylayıcı bir terapiste, sesli bir şekilde konuştuğunda duygu ve düşünceleri aydınlığa kavuşur ve düzenlenir. Böylece hasta duygusal bir rahatlama yaşar. Benzer şekilde dua da içten içe konuşan kişinin kendi kendinî dinleyerek duygu ve düşüncelerini aydınlığa kavuşturmasına yardım eder. Duada onaylayıcı terapistin yerini kendisine yalan söylenmesi imkansız bir Tanrı tasavvuru alır. ${ }^{53}$ Bireysel dua "gerçek ben” in açı̆̆a çıkmasını sağlayabilir. Merhametli ve bağışlayan bir Tanrı tasavvuruna yapılan "itiraflar," affedilme beklentisi nedeniyle suçluluk ve suçluluk ilintili stresi rahatlatır. ${ }^{54}$

Koç ${ }^{55}$ ergenler üzerinde yaptığı çalışmasına atıfla duanın, "derin bir varlığın, ergenin benliğinde gizli kalmış kısımların ortaya çıkarılmasını ve normal bilince yabancı gelen bazı durumların kavranmasını” sağlayabileceğini önerir. Yapılan araştırmalara dayanarak alçak sesle yapılan ciddi anlatımların, bireyin psikolojik yapısının alt bölümlerinde, iç güdüsel ve bilinç dışı kalan geçmiş yaşantıların olduğu bölümlerde etkili olduğunun belirlendiğini, aynı üslupla yapılan duanın da fiziksel ve ruhsal rahatsızlık durumlarında etkin rol oynayarak, bilincin karanlık bölgelerini etkilemek suretiyle ergende bir sükunet hali oluşturabileceğini belirtir. Dua etmek, stresten kaynaklanan gerginliğin hafifletilmesine yardım eder. Çünkü inanan ergen, problemlerinin çözümünde ve ihtiyaçlarının giderilmesinde kutsal varlığın kendisine yardımcı olacağını, ondan üzüntü ve kaygıyı kaldıracağını ümit eder. Dua ederek yaşadağ 1 tecrübeler de sinir sisteminin dengesini yeniden düzenleyerek, sinir sistemini kuvvetlendirir.

50 Aktaran Levine, "Prayer as Coping", s. 83.

51 Capps, "İstek Duası (Petitionary Prayer) Psikolojisi”, s. 164.

52 Gubi, "An Exploration of the Use Of Christian Prayer in Mainstream Counselling”, s. 433.

53 Ho, Chan, Peng \& Ng’nin çalışmalarından aktaran Levine, "Prayer as Coping", 84; Koç, "Ruh Sağlığı ile Dinî Başa Çıkma Metodu Olarak Dua ve İbadet Fenomeni Arasındaki İlişki Üzerine Psikolojik Bir Yaklaşım”, s. 29-30.

54 Levine, "Prayer as Coping", s. 84.

55 Koç, “Dua ve İbadetin Ergenlerin Ruh Sağlıklarına Etkileri Üzerine Teorik Bir Yaklaşım”, s. 81-82. 
Dua eden kişinin tasavvurundaki Tanrı ${ }^{56}$, Kitab-1 Mukaddes'te anlatıldı̆̆ 1 gibi güçlü, her şeye kadir ve her daim mevcut bir Tanrı ise, problemi betimleyen konuşma potansiyel olarak sınırsız bir kabiliyete sahip bir destek kaynağına atfedilir. Dindar kişiler arasında “Tanrı her şeye kadirdir” ifadesi oldukça yaygın bir söylemdir. Eğer Tanrı kişinin destek grubunun bir üyesi ise bu durumda Tanrı'nın destekleyici olduğu algısı (algısal destek) dua doğrudan yanıtlanmamış olsa dahi (erişilmiş ya da kabul edilmiş destek) stresin rahatlatılması için yeterlidir. ${ }^{57}$ Tanrı'yı bir mevcudiyet olarak algılamak ve aracı figürler vasıtasıyla bile olsa Tanrı ile irtibat kurmak duygusu, Tanrı'ya atfedilen destekleyici nitelik sebebiyle yalnızlık duygusunun azaltılmasını sağlayabilir. ${ }^{58}$

Kirkpatrick Tanrı'yı, varlığg bebeği rahatlatan anneye benzeterek "bağlanma nesnesi” olarak niteler. Tanrı'ya inanan bir bireyin varlığı kendisini rahatlatan Tanrı’nın ihtiyaç duyduğu her an kendisi için mevcut olacağını bilmesi onun yoğun ya da kronik korku hissetme eğilimini azaltır. ${ }^{59}$

Duanın insan psikolojisi üzerindeki etkilerini başa çıkma yöntemi bağlamında değerlendiren Levine, ${ }^{60}$ dua etmenin problemlerle başa çıkmada pasif bir başa çıkma metodu olarak görülse de aslında pek çok durumda aktif bir metot olduğunu savunur. Kişi dua ettikten sonra problemin yükünün üzerinden kalktığına ve şimdi artık problemin “Tanrı’nın elinde olduğuna" inandığında aslında problemi bir süreliğine askıya almış olur. Dua etmek durumu değiştirmese de kişinin durumu kavramsallaştırmasını değiştirir (başa çıkmada ikincil kontrol). Problemi Tanrı'ya havale eden kişi duygusal bir mola alarak problemi başka bir biliş seviyesinde çözmek için ortam sağlamış olur. "Mola”yı takiben problem çözmede kuluçkaya yatma olgusu oldukça meşhurdur. Davidson, molanın, kişinin üretken olmayan yaklaşımları elemesine ve daha sonra daha faydalı çağrışımların ortaya çıkmasına imkan sağlayacağını belirtir ${ }^{61}$. Kuluçka döneminden sonra ortaya çıkan çözüm duaya yanit olarak da değerlendirilebilir. Problemi Tanrı'ya havale etmek "manen teslim olmak" fikrine benzer ve kontrol edilemez olaylar üzerinde kâmil bir kontrol elde etme çabasına engel olur. Böylece kişi enerjisini beyhude bir arayışa harcamayı bıraktığı için rahatlar. ${ }^{62}$

“Doğru şeyi mi yapıyorum?” ya da “yapmam gereken doğru şey hangisi?” soruları stresli hayat olaylarının kişiyi maruz bıraktığı ikilemlerin merkezinde yer alır. Dua etmek dinî değerleri öncelediği için duayı müteakip kuluçka evresinde ortaya çıkan çözümler

\footnotetext{
56 “Tanrı Tasavvuru” hakkında geniş bir değerlendirme için bk. Ali Ulvi Mehmedoğlu, Tanrıyı Tasavvur Etmek.

57 Levine, "Prayer as Coping", s. 84.

58 Levine, "Prayer as Coping", s. 85.

59 Levine, "Prayer as Coping", s. 84.

60 Levine, "Prayer as Coping", s. 86.

61 Levine, "Prayer as Coping", s. 86.

62 Levine, "Prayer as Coping”, s. 86.
} 
dinî değerlerle uyumlu olacaktır. Bu da kişiyi ikilemi çözmek için "doğru” eylemi yapmaya teşvik edecektir. ${ }^{63}$

Dua etmek dinî bir görev olarak görülmektedir. Dinî inanç ve uygulamalarla sosyalleşen kişiler dua edemez iseler kendilerini huzursuz hissederler ancak dinî görevlerini yerine getirdikten sonra rahatlarlar. Dolayısıyla kişi bir görevi yerine getirdiği, ideal egoya ulaştığı için kendine saygısı gelişir. "Doğru şeyi yaptım ya da iyi bir şey yaptım, dolayısıyla ben iyi bir insanım” ifadesini söyleyebilmek çözüm yoludur. ${ }^{64}$

Duada ümit duygusu ve geleceğe yönelim vardır. Durum mevcut anda ne kadar umutsuz olursa olsun Tanrı gelecekte bu durumu değiştirebilir. Ümit ve optimist gelecek yönelimi ise korku ve ümitsizlik duygularının, destekleyici bir Tanrı imgesine yakarmak da yalnızlık duygusunun panzehiridir. Dolayısıyla dua etme eylemi düşünceyi destekleyici bir Tanrı’ya yönlendirmek suretiyle acil bir rahatlama ve gelecek yönelimli ümit duygusu uyandırarak kişiyi stresten uzaklaştırır. ${ }^{65}$

Psikoterapide kullanılan serbest konuşma tekniğindeki gibi dua, duyguların ve düşüncelerin düzenlenmesinde, duygusal boşalımda bir katarsis rolü üstlenebilir. Bağlanma teorisine göre dua, varlığı güven veren Tanrı'nın ihtiyaç duyulduğu her an mevcut olduğunun bilinmesinin bireyin kronik korkuya ve endişeye kapılma riskini düşürme rolü oynar. Başa çıkma teorisi de duanın kişinin stresli hayat olaylarıyla baş edebilmesinde önemli bir rol oynadığını savunur. Dua eden kişi problemi Tanrı’ya havale eder. Böylece bilişsel olarak olayı yeniden değerlendirmek ve çözüm yollarını değerlendirebilmek için bir mola vermiş olur. Mola sonrası dinî değerlerle uyumlu bir çözümün ortaya çıkması büyük bir olasılıktır. Ayrıca dua gelecek yönelimli umut duygusu da taşır. Teslimiyet, kontrolümüz dışındaki hayat olayları üzerinde kontrol sağlamaya çalışırken beyhude enerji harcayarak yıpranmamizı da engeller.

\section{Dua Sağlığı Nasıl Etkiliyor?}

Son yıllarda duanın sağlık üzerindeki etkilerinin anlaşılması ile birlikte çalışmalar kişinin fiziksel, davranışsal ve duygusal durumlarını gerçekten etkileyip etkilemediğine ${ }^{66}$ yo-

63 Levine, "Prayer as Coping", s. 87.

64 Levine, "Prayer as Coping", s. 87.

65 Levine, "Prayer as Coping”, s. 88; Pınar, Duanın Ruh Sağlığı Üzerindeki Etkileri, s. 14.

66 Johnson-v.dgr., "Centering Prayer for Women Receiving Chemotherapy for Recurrent Ovarian Cancer: A Pilot Study", s. 421-428; Andersson, "Chronic Pain and Praying to a Higher Power: Useful or Useless?", s. 176-187; George, Is Prayer Beneficial; Whittington-Scher, "Prayer and Subjective Well-Being: An Examination of Six Different Types of Prayer", s. 59-68; Welker, Review of The Literature on Effects of Prayer on Patient Outcomes; Ross-v.dgr., "Prayer and Self-Reported Health Among Cancer Survivors in the United States, National Health Interview Survey, 2002", s. 931-938; Matthews-v.dgr., "Effects of Intercessory Prayer on Patients with Rheumatoid Artritis", s. 1177-1186; Leibovici, "Effects of Remote, Retroactive Intercessory Prayer on Outcomes in Patients with Blood-stream-infection: Randomised Controlled Trial", s. 1450-1452; Bernardi-v.dgr., "Effect of Rosary 
ğunlaşmıştır. Her ne kadar duanın etkinliğinin teste tabi tutulup tutulamayacağ konusu olsa da ${ }^{67}$ bu sürecin nasıl işlediğini inceleyen çalışmalar arasında da bir konsensüs mevcut değildir. Makalemizin bu bölümünde duanın sağlığı nasıl etkilediğini açıklamaya çalışan çalışmalardan faydalanarak sürece 1şık tutmayı amaçlamaktayız.

Spring ${ }^{68}$ Encountering God: A Grounded Theory Of Prayer in Illness adli tezinde Epperly'den nakille, duanın nasıl "işlediğini” anlamak için (aslında işliyor ise ve bu süreç anlaşılabilir ise) zihin/benden/ruh arasındaki bağlantıyı anlamamızın ve "çevreyi” lokal ve lokal olmayan nesne ve olayları içerir şekilde görmemizin gerekli olduğunu söyler. "Nedenselliği" doğrusal değil de çok faktörlü anlamak ve çevredeki kişilerle insan olmayan nesneler arasındaki ilişkinin önemini kabul etmek de problemin anlaşılması için elzemdir. Ancak bundan sonra dua, kişilerin başkaları ile yakın ilişki kurduklarında (kendileri ve Tanrı dahil), hastalıkla başa çıkmaya çalıştıklarında, sağlıkla ilgili kararlar verdiklerinde, sağlık ve refahı etkileme potansiyeline sahip bir etki değişkeni olarak değil de bir sürecin, işleyişin parçası olarak incelenebilir.

Duanın sağlığı desteklemekte nasıl etkili olduğunu açıklayan teorik modelleri açıklarken Breslin-Lewis'in kullandığ tabloyu biz de burada alıntılayacağ $1 z$. Bu tablonun dua-sağlık ilişkisini anlamlandırmakta yardımcı olacağını umut etmekteyiz.

Prayer Yoga Mantras on Autonomic CardioVascular Rhythms: Comparative Study”, s. 1446-1450; Dezutter-v.dgr., "Prayer and Pain: The Mediating Role of Positive Re-Appraisal", s. 542-549; Ai-v.dgr., "Prayer And Reverence In Naturalistic, Aesthetic, And Socio-Moral Contexts Predicted Fewer Complications Following Coronary Artery Bypass", s. 570-581; Hollywell, "Private Prayer as a Suitable Intervention for Hospitalised Patients", s. 637-651; Haley-v.dgr., "Relationship between Private Religious Activity and Physical Functioning in Older Adults", s. 305312; Simão-v.dgr., “The Effect of Prayer on Patients' Health: Systematic Literature Review”, s. 11; Alling, "Healing Effects of Belief in Medical Practices and Spirituality", s. 273-280; Dossey, "Prayer, Medicine, and Science: The New Dialogue”, s. 7-37; Krucoff-Crater, "What Do 'We' Want and Need to Know About Prayer and Healing?", s. 12591261. Olumsuz bakanlara örnek olarak bk. Masters-v.dgr., "Are There Demonstrable Effects of Distant Intercessory Prayer? A Meta-Analytic Review", s. 21-26.

Cohen-v.dgr., "Prayer as Therapy", s. 40-47.

68 Spring, Encountering God, s. 26. 


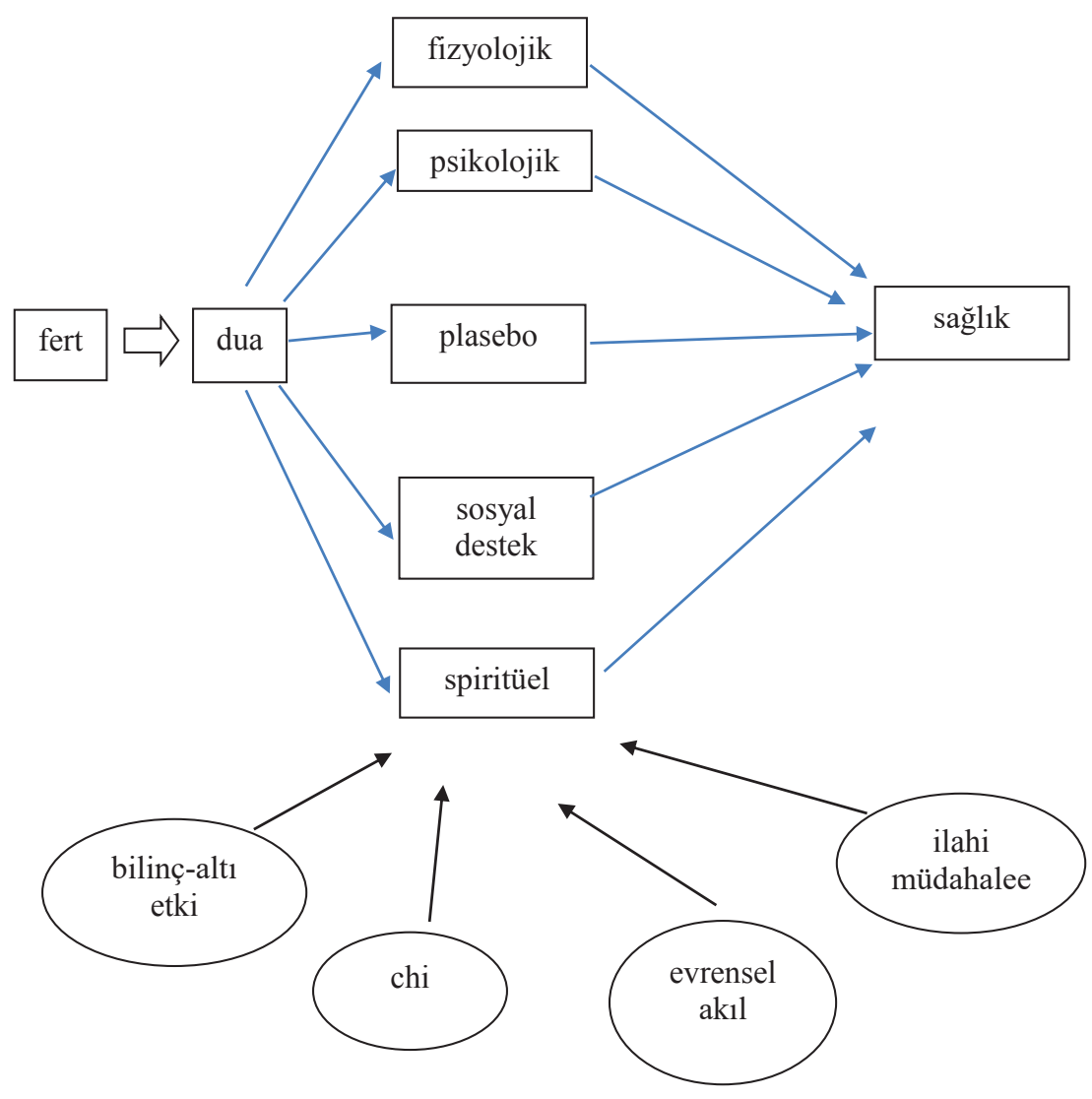

Şekil 1. Duanın Sağlığı Nasıl Etkilediğini Açıklayabilecek Teorik Modeller ${ }^{69}$

Tablo duanın sağlığı nasıl desteklediği konusundaki teorileri açıklamaktadır. Tablodan yola çıkarak duanın, pek çok dünya dininde de öğretildiği gibi, Tanrı’nın doğaüstü müdahalesi yoluyla sağlığı desteklediği kanısına varılabilir.

Duanın zamansal ve mekânsal etmenlerden bağımsız hareket ettiği düşünülmüştür. Dossey, duanın nasıl etki ettiğini açıklamaya çalışırken metafizik boyutu kullanır. Buna göre duanın etkisi mevcut an ya da gelecekle sınırlı olmayıp geçmişe de uzanabilir. Dossey bu olguyu zaman değiştiren dua (time-displaced prayer) olarak adlandırır. Dossey duanın haricî bir Tanrı'ya yönlendirilmediğini düşünür. Eğer Tanrı her bir bireyin içinde ise o halde duadaki ilahi faktör harici değil dahilidir. Zihne zaman ve mekânla yer tayin edilemez, aksine zihin ebedi ve bütündür. Bu da bize dua eden ile edilenin birbirinden son derece uzak

69 Breslin-Lewis, “Theoretical Models of the Nature of Prayer and Health”, s. 18. 
oldukları durumda dahi duanın nasıl etkili olduğunu açıklamak için yeterlidir. ${ }^{70}$ Dua edenler arasındaki bu zihin birliği evrende akarak kendisine bir yol bulur ve dua edilenler üzerinde pozitif bir etki yaratabilir. Sağlık üzerindeki bu pozitif etki duanın dua edenle dua edilenin zihinlerinin birbirlerine bağlandığı bir bilinç birliği oluşturarak, iyileşmenin iletimini sağlayan bir netice sağlayabilir. ${ }^{71}$

Levin’in ${ }^{72}$ lokal ve natüralistik açıklamalar arasında kabul edebileceğimiz açıklamasına göre, ampirik deliller olmasa da, dua gibi spiritüel uygulamalarla gizil güçler ya da enerjiler harekete geçirilebilir. O’na göre çeşitli kelimeler -örneğin chi ${ }^{73}$ ve prana ${ }^{74}$ gibi- bu farzedilen gücü ortaya çıkarmak için kullanılır. Levin bu güçlerin bedeni ve hastalığın ilerleyişini etkileyebileceğini düşünür. Quantum mekaniğinde istatistik öngörülerin çoğu Batılı bilim insanlarının inandıkları lokal evrenle açıklanamaz. Aksine olayların mekânsal uzaklıklarına bakılmaksızın, birbirini etkileyebildikleri, lokal olmayan bir evrenle açıklanabilir.

Bell'in "karşılıklı bağlantılı olma hali" (interconnectedness) teorisi de duanın etkisini yukarıdaki bağlamla açıllayan bir diğer teoridir. Buna göre "olaylar ya da objeler birbirinden soyutlanmış değildir. Bir bütün içinde birbirlerine entegre olmuş durumdadırlar. Hatta uzak nesneler bile ilişkili bir sistemin parçasıdırlar ve nesnenin birindeki bir değişim, birbirlerinden ne kadar uzak olurlarsa olsunlar, ötekinde de ani bir değişim yaratır." Bu teoriye göre hasta ile akrabaları arasındaki duygusal ve sosyal bağ, hastadan uzakta olduklarında bile hastaya dua etmek için bir araya geldiklerinde bir etki yaratır. Yine çeşitli çalışmalarda dua "iyileşmeyi destekleyen bir enerji transferi formu”, "bütün olarak görülen bir sistemde ilişkilendirici bir bağ", "olağanüstü iyileștiren yüce bir valıkla iletişim yolu" olarak görülür. Bir başka çalışmada ise duanın, sağlıkla ilgili davranışlar, sosyal destek, inanç psikodinamiği ya da psikonöroimmünoloji ${ }^{75}$ alanında stres tamponlayıcı gibi "yerel-natüralist" mekanizmaları harekete geçirmek yoluyla etkisini gösterdiği varsayılmaktadır. ${ }^{76}$

70 Breslin-Lewis, “Theoretical Models of the Nature of Prayer and Health”, s. 13.

71 Breslin-Lewis, "Theoretical Models of the Nature of Prayer and Health", s. 17.

72 Breslin-Lewis, “Theoretical Models of the Nature of Prayer and Health", s. 13.

73 Chi: Çi veya Japonca'daki söylenişiyle Ki, geleneksel Çin kültürü ve tıbbının temel kavramlarından biridir. Çi’nin mevcut olan her şeyde yer alan "hayat gücü" veya "spiritüel enerji” olduğuna inanılır. Genellikle "hava" veya "nefes" olarak yabancı dillere aktarılan bu terimin aslında tam bir karşılığı yoktur.

74 Prana: (Sanskritçe: “nefes") prãna olarak da hecelenir. Hint felsefesinde bedenin canlı "havası (airs)” ya da "enerji”"sidir. Upanişadlarda ifade edildiği gibi erken dönem Hint felsefesinde temel bir kavram olan prananın canlılık ilkesi olduğu düşünülmekteydi ve gelecekteki bir hayata kadar ya da ebedilik için kişinin "son nefesine" kadar yaşadığına inanılmaktaydı. Zaman zaman prana benlikle özdeşleştirilmiştir. "Beş prana” rüzgar benzeri hayati güçlerdir. Solumaya, yiyeceklerin bedende dağıtılmasına ve sindirime yardımcı olur. Yoga felsefesi pranayama uygulamaları vasıtasıyla prananın tam kontrolüne vurgular. Prananın tam kontrolü sağlandığında kişi solunum sisteminin dikkati dağıtmasını engellemiş ve hastalıklarda prayananın terapötik etkilerinden maksimum seviyede yararlanmış olur.

75 Psikonöroimmünoloji: Temel alanı sinir ve bağışıklık sistemleri ve ruhsal süreçlerle sağlık arasındaki ilişkiyi incelemektir. Psikonöroimmünoloji hastalık ve sağlıkta sinirsel bağışıklık sisteminin psikolojik işleyişini inceler; neuroimmüne sistem bozukluklarını (oto-immüne hastalıkları, aşırı duyarlılık, bağışıklık sistemi yetersizlikleri) ve neuroimmüne sistemin laboratuarda, oluştuğu yerde ve canlıda fiziksel, kimyasal ve psikolojik bileşenlerini inceler.

76 Spring, Encountering God, s. 6-7. 
Dua psikonöroimmünolojik geçiş yollarını uyarabilir. McCullough, duanın nöroimmünolojik, kardiovasküler ve beyin elektiriği değişimlerine neden olabileceğini ileri sürer. Dua rahatlamayı tetikler böylece sağlı̆̆ destekler. Rahatlama sağlanınca nabız düşer, kasların gerginliği azalır ve nefes alıp veriş hızı yavaşlar. ${ }^{77}$ Her ne kadar bir hasta dua vasıtası ile sağlığına kavuştuğunda sağlık çalışanları durumu plasebo etkisi ${ }^{78}$ olarak açıklasalar da Hughes bu durumun:

a. Duanın ortaya çıkardığı rahatlama ve huzurun endorfin salgılanmasını sitimule etmesi ve strese sebep olan merkezi sinir sisteminin eylemini bastırması,

b. Problemlerle başa çıkmada rahatlama ve etkinlik duygusu sağlaması ve

c. Duanın kullanımının bağışıklık sisteminin eylemlerini düşüren stresle ilgili hormonların eylemini azaltmasından kaynaklanabileceğini düşünür. ${ }^{79}$

Dossey duanın sağlığı etkilediğini açıklarken: a) duanın kollektif yönünün sosyal destek sağladığı, bu desteğin hastalığa karşı gizil koruyucu faktör oluşturduğu, b) dua psikodinamiğinin immüne ve kardiovasküler sistemi olumlu bir şekilde etkileyecek sayısız duygu değişimini tetiklemiş olma olasılığı, c) duanın plasebo etkisi yapmış olması ve d) dua konusu olmanın iyileşmeyi sağlayan endokrin ya da bağışıklık tepkisini harekete geçirebileceği şeklinde dört farklı açıklama sunar. Kendisi için dua edildiğini bilmek sağlığ destekleyecek aidiyet ve destek duygusu geliştirir. ${ }^{80}$

Dua eden fertlerin sağlık ilintili davranışlara yönelmeleri (sigara, alkol, beslenme, cinsel yaşam vb. konularda belirlenmiş ve yasaklanmış eylemler), sosyal destek (dinî katılımdan kaynaklanan), stres tamponlama (dinî eylemlerden kaynaklanan bedende fizyonöroimmünolojik yollarla etkili olabilecek duyguların oluşması), bilişsel etki (özgür iradeye ve içsel kontrole inanmak) ve inanç psikodinamiği (yani Tanrı’nın iradesi bağlamında pozitif beklentilerle iyileşmeyi sağlayabilecek plasebo etkisi) de sağlık üzerinde pozitif yönlü bir etki yaratır. Kişinin iyileşme öznesi olduğunu bilmesi bizatihi iyileşmedir; çünkü bu onda bir aidiyet duygusu, önemsenme duygusu ve destek duygusu yaratır. ${ }^{81}$

Breslin-Lewis, duanın sağlık üzerinde nasıl etkili olduğunu araştırdığı çalışmasında "plasebo" etkisinden de bahsederler. Dua dikkati sağlık problemlerinden uzaklaştırmak ve hayat olaylarını yorumlarken bir çerçeve sunmak suretiyle faydalı olabilir. Dua anlam, umut, empati ve duyarlılık gibi pozitif duyguları meydana çıkarmak yoluyla psikolojik sağlığa fayda

77 Breslin-Lewis, “Theoretical Models of the Nature of Prayer and Health”, s. 12.

78 Plasebo etkisi: Etkisi olmayan bir madde ya da sahte bir süreçle yapılan terapiye atıfla kaydedilen psikolojik ya da psikofizyolojik gelişime denir. Tedavi için sahte bir madde verildiğinde bazı kişilerin olumlu yönde kayda değer bir gelişme göstermelerine açıklama getirilememektedir. Araştırmalar olumlu etkinin tedavinin doğrudan etkisinden ziyade kişinin tedaviden beklentisine olan inancından kaynaklandığına işaret etmektedir.

79 Breslin-Lewis, "Theoretical Models of the Nature of Prayer and Health", s. 12.

80 Breslin-Lewis, "Theoretical Models of the Nature of Prayer and Health", s. 13.

81 Breslin-Lewis, “Theoretical Models of the Nature of Prayer and Health", s. 13. 
sağlayabilir. Şefaat duasının yarattığı empati iyileşmeye neden olabilir. Dahası, eğer fertler kendi iradelerini dua vasıtasıyla Tanrı’nınki ile aynı yöne yöneltebilirlerse böylece benlik saygısı gelişebilir. ${ }^{82}$ Muhtemelen, dua "yalvarma ve istediğini elde etme meselesi olarak değil de kendimizi kendi manevi doğamızla aynı eksene getirme anlamına geldiğinde, Tanrı’nın hakkımızda planladığı şeyi daha kolay kabul eder hale gelmemiz de duanın sağlık üzerinde etkili olmasının bir diğer nedeni olabilir. ${ }^{83}$ Yüce bir güçle kurulan algısal bir ilişki sosyal desteğin sağladığı aynı faydayı sağlayabilir.

Breslin-Lewis, duanın tabiatını ve sağlıkla ilişkisini incelediği çalışmalarında özetle duanın sağlığı şu şekillerden biriyle etkilediğini ileri sürerler:

a) dua plasebo etkisi nedeniyle sağlığ geliştirir,

b) dua eden kişiler sağlıkla bağlantılı davranışlar sergileyebilir,

c) dua kişinin dikkatini sağlıkla ilgili problemlerden başka yöne çevirmek suretiyle yardımcı olabilir,

d) dua Tanrı’nın olağanüstü müdahalesiyle sağlığı destekler,

e) empirik olarak doğrulanmamış, ancak sağlığa faydalı, chi gibi gizli bir enerjiyi aktifleştirebilir,

f) dua fertler arasında iyileşmenin iletimini kolaylaştıracak bir bilinç birliğine neden olabilir, şeklinde özetler.

Duanın sağlığı nasıl etkilediği konusuyla ilgili alanyazındaki çalışmaları değerlendirdikten sonra şimdi de kişiler üzerinde oldukça etkili olan böyle bir destekleme metodunun, sağlık çalışanları ve manevi danışmanlar tarafından nasıl kullanılması gerektiğini değerlendireceğiz.

\section{Dua, Manevi Danışmanlıkta Nasıl Kullanılmalıdır?}

Hasta ziyareti semavi dinlerde tavsiye edilen bir erdemdir. "Hastayı samimi bir şekilde desteklemek ve rahatlatmak arzusu, ona umut vermek, inancını desteklemek, optimizm uyandırmak, iç gerilimi ortadan kaldırmak, depresyonu gidermek ve orada olmakla soyutlanmışlı̆̆ engellemek" ${ }^{4}$ hasta ziyaretlerinde ziyaretçiyi motive eden unsurlardır. Hıristiyan geleneği "Hasta idim ve beni ziyaret ettin" 85 âyetiyle hasta ziyaretini teşvik ederken; İslâm bir müslümanın diğer bir müslüman üzerindeki haklarını sayarken ${ }^{86}$ bunlardan birinin

82 Breslin-Lewis, “Theoretical Models of the Nature of Prayer and Health", s. 17-19.

83 Murray, "Prayer as Coping", s. 55.

84 Kirkwood, Pastoral Care in Hospitals, s. 100.

85 Matta, 25/36.

86 Hadisin tam metni şöyledir: "Müslümanın müslüman üzerinde beş hakkı vardır: Verilen selama mukabele etmek, hastayı ziyaret etmek, cenazesine katılmak, davetine icabet etmek, aksırdığı vakit yerhamukellah demek" (Buhârî 
de hasta müslümanların ziyaret edilmesi olduğunu belirtir. Hıristiyan geleneğinde Kutsal Kitab’ın yukarıdaki emrinin yerine getirilmesi amacıyla kiliseye bağlı din görevlileri kendi bölgelerindeki hastanelerde yatan cemaat üyelerini düzenli olarak ziyaret ederler. Ayrıca 1950’lerden sonra Batı'da hastaneler bünyelerinde hastaların, çalışanların ve hasta yakınlarının manevi ihtiyaçlarının karşılanması amacıyla manevi danışmanlar (chaplains) çalıştırmaya başlamışlardır. Ülkemizde de 2015’te Sağlık Bakanlığ ile Diyanet İşleri Başkanlığı arasında imzalanan protokol gereği artık hastaneler bünyelerinde manevi danışmanlar görevlendirmektedirler. Gerek hasta yakınlarının, gerek din görevlilerinin, gerekse manevi danışmanların hasta ziyaretlerinin en belirgin niteliğini dualar oluşturur. Her ne kadar manevi danışmanın hasta ziyaretinde dua ederken amacı genellikle manevi rahatlık sağlamak ve ümit vermek olsa da danışmanların zaman zaman çok konuşan hastalardan sakınmak, bazen de hastanın gündeme getirdiği meselelerden kaçmak için dua etmeyi bir kaçış yolu olarak kullandığı da bir gerçektir. Duanın amacı dışında kullanımı etkinliğini zayıflatır ayrıca hastanın inancına da zarar verir. Bu nedenle ziyaretçinin ya da manevi danışmanın ne zaman, nasıl dua edilmesi gerektiğini ve olası tehlikelerin neler olabileceğini bilmesi gerekir.

Duanın ne zaman kullanılacağı ile ilgili geleneksel iki anlayış mevcuttur. Bunlardan birincisi "her ziyarette dua edilmesi gerektiğini" savunurken, diğeri "sadece talep edildiği takdirde dua edilmesi gerektiğini” düşünür. Din görevlileri hastayı her ziyaret edişte dua etmenin gerekli olduğu yönündeki yaygın algının yanında, kendi rollerini muhafaza etmek ve bir imaj oluşturmak için de duayı kullanırlar. Bu durumlarda hasta istesin ya da istemesin dua başarılı bir ziyaretin temel malzemesine dönüşür. Dolayısıyla dua ederken kimin ihtiyacının karşılandığı sorgulanmalıdır. ${ }^{87}$ Silton ve arkadaşları her ziyarette dua edilmesi gerektiği algısına işaret ederek bunu manevi danışmanların hasta ziyaretinin bütünleyici bir parçası olarak gördüklerini aktarırlar. Evenson ve arkadaşlarının yaptığı çalışmaya atıfta bulunarak, manevi danışmanların hastanın manevi geçmişini elde etmek ve "hastanın manevi gidişatını" değerlendirmek amacıyla, dua etmenin bir metot olarak kullanılabileceğini ileri sürdüklerini belirtir. Bu durumda duanın, manevi danışman ile hasta arasındaki bağı desteklediği ve hastanın kendi dinî geleneği ile bağlarını yeniden onardığ ya da güçlendirdiği düşünülür. ${ }^{88}$

Duayı her ziyaretin kesin bir kuralı haline getirmek ve bu şekilde kullanın bazı sakıncaları vardır: Dua ritüelleşir, genelleşir, yüzeyselleşir, dindarane ifadeler kullanılması dolayısıyla duanın anlaşılması engellenir, dua eden otoriterleşir ve dua edenin kendinî beğenmişliğinin ifadesine dönüşür. Şimdi Kirkwood'un hastanelerde manevi bakımın nasıl olması gerektiğini incelediği çalışmasından faydalanarak ${ }^{89}$ bunların ne anlama geldiklerine kısaca bakalım.

\footnotetext{
“Cenâiz”, r. 1240; Müslim, “Selâm”, r. 4; Ahmed b. Hanbel, II, 321, r. 8271).

87 Levine, "Prayer as Coping", s. 100.

88 Silton-v.dgr., "Pray Tell: The Who, What, Why, and How of Prayer Across Multiple Faiths", s. 42.

89 Kikwood, Pastoral Care in Hospitals, s. 100-103.
} 
Din görevlisinin duayı her ziyaretinin olmazsa olmaz bir parçasına dönüştürmesi duayı ritüelleştirir. Din görevlisi bir dua kitabı ya da hasta ziyaretinde okunacak duaları ihtiva eden din görevlisi el kitabı tarzında bir kaynağı yanında taşıma eğilimi gösterir. Bu dualar ezberden okunduğunda neredeyse kelimeler söylenmeksizin geçilir. Hasta duayı samimiyetsiz, hatta ilgisiz bulabilir. Manevi danışman sadece beklenen rolünü yerine getirmiştir. Dua hasta açısından sadece ritüel yükümlülükleri yerine getirmenin dışında daha kişisel bir anlam ifade etmelidir. ${ }^{90}$ Silton ve arkadaşları ${ }^{91}$ manevi danışmanlar ile yaptıkları araştırmada, Protestan manevi danışmanların her ziyarette dua etmenin "kolay bakım uygulama" olarak görüldüklerini aktarırlar. Yahudi manevi danışmanlar ise her zaman dua etmenin gereksiz olduğunu ancak bazı özel durumlarda (örneğin ameliyat öncesi, kişi endişeli olduğunda) dua edilebileceğini bildirdiklerini aktarır.

Her ziyarette dua edildiğinde yineleyen bir dua modeli gelişir. Yapılan her dua genellikle biraz teoloji, biraz hastane çalışanlarına minnet, biraz hastanın iyileşmesine -hastalığın iyiye gidişi zayıf olsa bile- şükran ve nihayet hastanın ailesine (genellikle ayrıntıları belirsiz) dua etmek gibi nitelikler kazanır.

Dualar yüzeyselleşebilir. Sürekli dua eden manevi danışmanlar ya din görevlisi olarak kendi becerilerine çok fazla güvenirler ya da çok endişeli ve ne söyleyeceklerini bilmeyen kişilerdir. Kendilerine çok fazla güvenenler, daha önce bunu pek çok kez yaptıklarından kontrol onlardaymış gibi mutlu bir şekilde fazla düşünmeksizin dua ederler. Tecrübesiz, endişeli ve ne söyleyeceğini bilemeyen din görevlileri ise geldikleri kurumun (kilise, cami vb.) bilindik tonuyla dua ederler. Tecrübesizliğin verdiği acemiliği, utancı ve hatta hastayla özdeşleşme korkusunu gizlemek çabası onları duaya iten bir diğer etkendir. Böylesi bir ziyarette hasta ile ilişki ve dua yüzeysel bir seviyede kalır. Hasta böylesi bir ziyaretten rahatsız olur ve hatta kızgınlık bile duyabilir.

Dindar, vazifeşinas manevi danışmanlar genellikle ilk çocukluk döneminde dinî bir yetiştirmeye maruz kalmışlardır. Eğer hastanın yanı başında eski dindarane, tumturaklı konuşma duada yinelenirse hiçbir şekilde hastanın durumuyla uyuşmayan bir duygusallık ortaya çıkar. Hatta aktif cemaat üyeleri bile bazen bu tarz aşırı dindarane dualardan rahatsız olurlar. Kullanılan dinî dil ziyaretin anlamını ve niyetini saptırır. Hasta danışmanın ne demek istediğinden şüphe duymaya başlar.

Hasta ziyareti bir tür sorumluluk hissi de taşımalıdır. Manevi danışman işinde ne kadar ehil olduğunu kanıtlamak için duayı bir araç olarak kullanmamalıdır. Duayı kendi ehliyetlerinin bir göstergesi olarak kullanan kişilerin duaları süslüdür, ilahi kitaba dair geniş bilgilerini ve Tanrı'ya derin saygılarını sergiler. Duaları kendinî beğenmişliklerini ifşa etmek için kullanirlar.

\footnotetext{
90 Kirkwood, Pastoral Care in Hospitals, s. 100-101.

91 Silton-v.dgr., "Pray Tell: The Who, What, Why, and How of Prayer Across Multiple Faiths", s. 49.
} 
Dua etme eylemi din görevlisinin öteki üzerindeki otoritesini kanttlamak için de kullanılır. Dua etme görevi yerine getirilinceye kadar duacıda içsel bir gerilim mevcuttur ve görev tamamlanana kadar yönetimi ele alır. Süreci düzenleme, zamanlama bir prestij meselesidir. Çoğunlukla bu baskı "dua edelim" emri ya da daha tepeden bakan bir şekilde "sizinle dua etmemde bir sakınca var mı?” ifadesine kadar devam eder. İkinci emir kendisini bir esir gibi hisseden hastaya gerçekte hiçbir seçenek bırakmaz. Hasta inandığı dinî temsil eden bu otorite figürünü mutlu etmek zorundadır. Hasta kaçamayacağı bir tuzağın içindedir. Takip eden duaya yavaş yavaş hastanın bağımsızlığını ve saygınlığını suistimal eden bir haşlama da eşlik eder. Kendisine verilmiş görevi yerine getiren görevli bu durumu farkedemez. Din görevlisinin hastaya kibarca "Sizinle dua edebilir miyim?" şekindeki sorusu bile hastayı zor duruma düşürebilir. Hastanın dua teklifini peşinen reddetmesi onu "maneviyatsızlıkla" yargılanmaya açlk hale getirir. O halde dua nasıl teklif edilmelidir? "Sizinle bugün ya da başka bir zaman dua etmemi ister misiniz?" şeklindeki bir soru hastayı utandırmayı engeller ve hastaya başka bir zaman deme özgürlügünü verir. Hal böyleyken bile hasta reddettiğinde kendisini suçlu hissedebilir. Eğer bu olasılık mevcut ise şöyle rahatlatıcı bir ifade kullanılabilir: "Bazen yapmayı isteyeceğimiz son şey dua etmektir. Tanrı böyle hissettiğimizde bizi anlayacaktır. Eğer benim dua etmemi istemiyorsan sorun değil."

Bir diğer seçenek hasta ile sadece talep etmektir. Bu hasta ile beraber olma sorumluluğunu yerine getirmede en kolay yoldur. Bu yaklaşım manevi danışmanın dua ederken ne söyleyeceğini bilmeme beceriksizliğinden ve tarafları dua etme talebinin reddedilmesi durumundaki utançtan korur. Ayrıca duada sahtekarlığı, samimiyetsizliği engeller.

Manevi danışman hastane ortamında çok farklı vakalarla karşılaşır. Çocuğu şiddetli bir beyin hasarı gördügü için yoğun bakımda yatan bir ebeveynden, lösemi ya da AİDS hastasına kadar çok çeşitli vakalarla karşılaşıldığında danışman niçin ve nasıl dua edeceğini bilemeyebilir. Dua edebilmek ya da duaya ihtiyaç olup olmadığını bilebilmek kişinin ne hissettiğine yoğunlaşmasını gerektirir. Ancak ağır vakalarda hasta kendini geri çekmiş ve hasta yakınları onun yerine konuşuyor olabilir. Bu durumda akrabaların ihtiyaçlarının mı yoksa hastanın arzularının mı karşılanması gerektiğine karar verilmelidir. Eğer dua etmek için herhangi bir talep yoksa sadece istenildiğinde dua etmelidir. Hastanın ve ailenin çok iyi seçilmiş dua ifadelerinin desteği ve konforunu sıcak karşılayacak pek çok fırsatı olacaktır. ${ }^{92}$

Dua etme teklifi reddedildiğinde bu hem hastada hem de manevi danışmanda bir utanç duygusu yaratır. Dinî otoriteyi temsil eden birini reddetmek oldukça cüretkar bir davranıştır. Hastalar bazen gelen danı̧̧manın samimiyetini denemek için de böyle davranırlar. Eğer danışman samimi ise, reddedilmişliğe rağmen tekrar tekrar geri gelecektir. Ancak duanın sadece talep dahilinde edilmesi duadaki sahtekarlığ da engeller. ${ }^{93}$

92 Kirkwood, Pastoral Care in Hospitals, s. 103-104.

93 Kirkwood, Pastoral Care in Hospitals, s. 104. 
Manevi danışmanlar zamanlarının kısıtlı olması, kişisel olarak kendilerini rahat hissetmemeleri, bilgisizlik ya da tecrübesizlik, özel alan olmaması, hasta ile dua etmenin uygun olup olmadığına karar vermede güçlük çekmeleri gibi nedenlerle ${ }^{94}$ hasta ile dua etme ya da dua konusunda konuşmalarının doğru olup olmayacağını bilemezler. Bu nedenle manevi danışmanlar dua etmeyi teklif etmeden önce bir ön değerlendirme yapmalıdırlar.

\subsection{Dua Etme İsteğinin İşaretleri}

Din görevlisi ikinci türde yaklaşımı benimsiyor ise dua etme teklifinin hangi durumlarda uygun bir teklif olacağını bilmesi gerekir. Dua etmeyi teklif etmek noktasında hastanın açık talebinin dışında bazı işaretler de mevcuttur. Taylor ${ }^{95}$ bu yollardan birinin hastane kabul formunda bulunan dindarlıkla alakalı alandaki bilgi olduğunu aktarır. Manevi danışman ile hasta arasında kurulan ilişkinin kalitesi de dua etme talebinin nasıl karşılanacağını belirleyen bir unsurdur. Toplumda dua edenlerin genellikle kimler olduğu bilgisi de yardımcı bir bilgidir. Hastaların pek çoğu özel hayatlarında dua ediyor olsalar bile bu onların danışman ile birlikte dua etmeyi isteyecekleri anlamına gelmez.

Taylor ve Kirkwood’a göre, "hasta ile yapılan sohbetler esnasında hastanın hikayesini anlatırken verdiği ipuçları” değerlendirme yapılırken esas alınması gereken en temel kriter olmalıdır. Hastanın dua ile ilgili açıkca konuşması bir işarettir. Bu basit bir "Bana dua eden pek çok kişi var", "Kızım ve arkadaşları bana dua ediyorlar" ya da "Ben dindar biri değilim ama hastalandığımdan beri dua ediyorum" gibi basit bir ima olabilir. Bu tarz kişilerin dua teklifinden memnun olacakları düşünülebilir. Pek çok durumda hasta "Nasıl dua edeceğimi bilmiyorum" şeklinde yanıt verebilir. Bu, duanın sadece Tanrı ile konuşmak olduğunu söylemek için iyi bir fırsattır. Dua ettiğinde Tanrı’ya içinden gelenleri söylersin. Manevi danışmana ipucu veren bir başka durum dinî konuşmalardır. Düzenli bir şekilde ibadet etmeyen ya da sözde dindarlar genellikle hasta ziyaretlerini hoş karşılar. Bu kişiler düzenli ibadet etmemelerine çeşitli bahaneler ileri süreceklerdir. Bu tarz ifadeler onların kendi dinî tembellikleri için duydukları suçluluk duygusunu hafifletir. Ancak danışman bu tarz ifadeleri dua için beklenti şeklinde yorumlamamalıdır. Dua etmek için elverişli zamanın hangisi olduğuna karar verebilmek basiret gerektirir. Çünkü dua her zaman arzulanmaz. Erken yapılan bir teklif doğru zamanı araştırmayı engeller. İste bu durumlarda dengeyi korumamız gerekir. ${ }^{96}$

Yatağın baş ucunda bulunan dinî literatür bu konuda bize yardımcı olacak bir diğer işarettir. Bu tür malzemelerin varlığı kişinin dindar biri olduğunu ve duayı reddetmeyeceğini gösterse de bazen bu tür malzemeler yanlış anlamalara neden olabilir. Hastanın manevi huzuruyla alakadar olan dindar bir anne ya da komşu hastanın bunları alabileceği, okuyacağı ve ihtida edebileceği umuduyla getirmiş olabilir. Çevreden gelen bu tarz bir baskı hastada

\footnotetext{
94 Taylor, "Prayer's Clinical Issues and Implications”, s. 185.

95 Taylor, "Prayer's Clinical Issues and Implications”, s. 180.

96 Taylor, "Prayer's Clinical Issues and Implications”, s. 180; Kirkwood, Pastoral Care in Hospitals, s. 106-108.
} 
dindar kişilere karşı düşmanlık duygusu yaratabilir. Dolayısıyla manevi danışman önce hastanın güvenini kazanmaya çalışmalıdır. Dua etmeyi teklif etmeden evvel ziyaretin bir evresinde başucundaki bu malzemeler ilgi odağı haline getirilmek suretiyle hastanın yaklaşımı anlaşılmaya çalışılmalıdır. Eğer rahatsızlık ya da utanç işaretleri mevcut ise konudan uzaklaşıp, uygun zaman gelene kadar dua önerisinden vaz geçmelidir. ${ }^{97}$

Mevcut bir endişenin manevi danı̧̧man ile paylaşılması da bir başka işarettir. Dindar olsun ya da olmasın bazı kişiler çok derin problem veya endişelere sahiptirler. Bir din görevlisi olarak sizin güvenilir olduğunuz ve mahremiyete saygı duyduğunuz düşünülür. Dinle özdeşleştirilmeniz, Tanrı̉ya erişiminiz olduğu varsayımına yol açar. Hastanın içinde bulunduğu durum nedeniyle bazen insani bir çözüm yeterli olmaz. Manevi danışman açıkça bunu ifade ettiğinde dua teklifi kabul görebilir ya da hasta sadece "beni dualarında unutma" diyebilir. Hasta ikincisini tercih ederse danışman buna uymalıdır. ${ }^{98}$

Dua teklifinin uygun olup olmadığına karar vermenin bir diğer yolu da aileden ya da hastane çalışanlarından edinîlecek bilgidir. Bazen hastalar manevi problemelerini yakınlarındaki kişilere açarlar. Eğer aile ya da hastane çalı̧sanlarından biri size bunlardan bahseder ve hasta ile ilgilenmenizi isterse bu durumda hastanın onayının alınıp alınmadığından emin olunmalıdır. Eğer böyle bir müsaade verilmemiş ise bilgiyi verenin izin alması talep edilmeli ya da danışman hiçbir şey olmamış gibi hastayı ziyaret edip konuyla ilgili konuşma ortamı hazırlamaya çalışmalıdır. ${ }^{99}$

Manevi danışmanın manevi sezgileri bütün yukarıdaki unsurlarla birleştirildiğinde doğru kararın alınmasında yardımcı olacak ${ }^{100}$ bir diğer unsurdur.

Danışman dua teklifinin hastayı gücendirmesi ihtimalinden çekinirse bu durumda danışmanın hasta ile ilişkisinin terapötik olup olmadığına ve dua etmeyi etik bir şekilde teklif edip etmediğine bakması gerekir. Durum böyle ise hastayı gücendirme ihtimali düşüktür. Ancak dua ile ölümü özdeşleştiren hastalar, danışman hastaya dua etmeyi isteyip istemediklerini sorduklarında paniğe kapılabilirler. Hasta ile dua etmenin etik olacağını değerlendiren bir danışman, dua etmeyi gerektirecek tıbbî bir durumun olmadığı konusunda hastaya güvence vermelidir. Genellikle danışman saygıll, şefkatli ve etik bir şekilde dua etmeyi önerir ise saygı ve şefkat manevi danışmanın dua içeriğinin ya da tarzının sebep olabileceği olası kusurların etkisini azaltacaktır. ${ }^{101}$

Manevi danışman hastayla dua etmenin uygun olduğu kanısına vardığında göz önünde bulundurması gereken bir diğer husus dua ederken nelere dikkat etmesi gerektiğidir. Şimdi de kısaca bunları inceleyelim.

\footnotetext{
97 Kirkwood, Pastoral Care in Hospitals, s. 107; Taylor, "Prayer's Clinical Issues and Implications", s. 180.

98 Kirkwood, Pastoral Care in Hospitals, s. 108.

99 Kirkwood, Pastoral Care in Hospitals, s. 108-109.

100 Kirkwood, Pastoral Care in Hospitals, s. 109; Taylor, "Prayer's Clinical Issues and Implications", s. 180.

101 Taylor, "Prayer's Clinical Issues and Implications”, s. 187.
} 


\section{Dua Ederken Nelere Dikkat Etmelidir?}

Hastalık hastanın fiziksel ve ruhsal durumunu etkiler. Dolayısıyla hastanın dua anlayışı, duanın muhtevası ve dua ediş şekli bundan etkilenir. Manevi danışman dua ederken öncelikle hastalığın duayı nasıl etkilediğini bilmelidir. Taylor’n duanın klinik problemlerini ve neticelerini ${ }^{102}$ incelediği araştırması bize bu konuda detaylı bilgi verir. Buna göre hastalık duanın sıklığını ve yoğunluğunu artırırken kişinin alışkın olduğu dua tecrübesini fiziksel olarak yerine getirirken bazı zorluklar yaşamasına sebep olabilir. Bunlar arasında diz kırmada zorlanma, nefes yetmezliği (bu yalnızca sessiz duanın edilebileceği anlamına gelir), ağrı ve mide bulantısı (imkansızlaştırmasa da dua etmeyi zorlaştırır), zihni uyuşturan ilaçlar, hastane ortamı (dua esnasında konsantre olmayı güçleștirir), halsizlik ve depresyon (dua etme isteğini ve enerjisini yok edebilir) saylabilir. Örneğin kardiyak hastalarının durumu ağırlaştı̆̆ında, hatta ölümleri yaklaştığında dua daha kısa ve mevcut duruma daha da yoğunlaşmış bir hal alır. Çok hasta kişiler sadece birkaç kelime ile dua edebilirler. Taylor, Hawley ve Irurita’nın çalışmasına atıfla araştırmalarına katılan katılımcıların belirli bazı faktörlerin hastaneye yattıkları dönemlerde dua etmelerini desteklediği bilgisini aktarır. Sessiz bir ortam, asgari rahatsız edilme, dua edecek kadar kendinî iyi hissetme, başkalarının kendinî düşündügünü ve ona dua ettiklerini bilmek (örneğin hastaya gönderilen geçmiş olsun kartları, çiçekler vs.) bunlar arasındadır.

Hastalık kişilerin dua inançlarında da kötü değişikliklere neden olabilir. Taylor ve arkadaşları kanseri yenen hastalarla yaptıkları bir başka araştırmalarında, hastaların dua ile ilgili tecrübe etmiş olabilecekleri pek çok manevi çelişkiyi gözlemlemişlerdir. Bunları şu şekilde formüle ederler: ${ }^{103}$

a. "Yanıtlanmamış" duaları merak etmek (ya da Tanrı’nın dualarını işitip işitmediğini ya da "olumsuz" yanıtladığı hakkında sorular),

b. Yakarış duaları hakkında tereddüt etmek (ya da dua eden kişiyi hayal kırıklığına uğramaktan koruyacak güvenli bir şekilde dua etmek; örneğin sadece genel şeyler istemek, kendisi için dua etmemek ya da iyileşme gibi belirli bir şeye dua etmemek),

c. Kontrol konusunda çelişki yaşamak (ya da kontrolü Tanrı̉ya bırakmak konusunda içsel bir gerilim yaşamak),

d. Hastalığın anlamını ve seven bir Tanrı̉nın olduğu dünyada kötülüğün varlığını sorgulamak (ya da hastalığın neden gerçekleştiğini ve hastalığın "büyük planda" nereye oturdugunu anlamaya çalışmak),

e. Tanrı’nın doğasını sorgulamak (örneğin, Tanrı beni duyuyor mu? Tanrı adil mi? Tanrı kudretli mi ya da gücünü benim faydama kullanmayı irade ediyor mu? Tanrı beni seviyor mu yoksa beni kullanıyor mu?),

102 Taylor, "Prayer's Clinical Issues and Implications", s. 182.

103 Taylor, "Prayer’s Clinical Issues and Implications", s. 182-183. 
f. Pazarlık etmek (örneğin Tanrı'dan yaşamak için daha fazla vakit istemek),

g. Duanın etkisinden şüphe duymak (ya da duanın gerçekten işe yarayıp yaramadığını merak etmek),

h. Kişisel maneviyat ve değerden şüphe duymak (yani “Tanrı'dan büyük şeylere erişmek için” kendisini değersiz hissetmek ya da dualarının iyi olmadığını ya da yeterince sık dua etmediğini düşünmek),

i. Doğru şekilde dua edip etmediği hakkında endişelenmek (yani dualarının aşırı derecede gevşek, aşırı derecede belirsiz, resmi ve yaratıcı olup olmadığını merak etmek).

Manevi danışmanın duayı kullanırken hastalığın kişinin fiziksel ve ruhsal dünyasında meydana getirebileceği bu ve benzeri olumsuz yönlerin farkında olması gerekir. Her ne kadar hastalığın bu manevi şüphe ve çelişkilere neden olup olmadığı tartışmalı bir konu olsa da hastalığın bunları yoğunlaştırdığı ve biliş seviyesine çıkardığı bir gerçektir.

Edilen duaların içeriğinin nasıl olması gerektiği de dikkat edilmesi gereken bir diğer konudur. Buna göre dua kısa olmalı, hastanın ve ilgili kişilerin ismini içermeli, bir araya gelişin ana nedenlerini belirtmeli, dinî jargondan uzak olmalı, umut aşılamalı, olmayan bir şeyi hastanın aklına sokmamalı, Tanrı’nın merhametini hatırlatmalıdır. Ayrıca çeşitli hedefler gözeterek dua etmek etik değildir. Dua ederken kullanılan dile ve bilgiye dikkat edilmelidir. Ana hatlarıyla bu şekilde sıralayabileceğimiz bu noktalara biraz daha ayrıntılı bakalım.

Hastaların konsantrasyon süreleri oldukça kısa olduğundan edilen dualar kısa olmalıdır. Bu tür hastalarla edilen dua 30 saniye ile bir dakika arasında olmalıdır. Yakarış hasta anlayabilsin diye kısa ve doğrudan olmalıdır. Çok hasta olmayanlar için dua biraz daha uzun olabilir ancak anlamlı ve alakalı olmalıdır. ${ }^{104}$

Duada hastanın ve ilgili kişilerin isimleri zikredilmelidir. Bu duayı özelleştirir. Hasta genellikle tramatize olduğundan temelde sevdiklerinin ve yakın arkadaşlarının iyi halleri onlar için öncelik taşır. Hasta ağır bir şekilde sakinleştirici aldığında sadece isimler hatırlanırken dua ile ilgili başka hiçbir şey hatırlanmaz. Bu isimleri işitmek herkesin Tanrı’nın koruyucu şemsiyesi altında toplandığı anlamına gelir. Bu çok rahatlatıcıdır. Genelleştirme gereksizdir, anlamsızdır ve bu dönemlerde zarar vericidir. ${ }^{105}$

Duada biraraya gelişin temel noktaları özetlenmelidir. Bu hastanın duygularını yorumlamaksızın veya bu duygularla tezat oluşturmaksızın yapılmalıdır. Hastanın zayıf konsantrasyonundan dolayı yapamadığı duayı onun adına manevi danışman yapmaktadır. Hastanın zihnini ve düşüncelerini onun adına Tanrı’ya siz sunarsınız. Bu hastayı ve akrabaları, olup bitenle ilgili kişisel yoruma yer vermeksizin dinlemeyi gerektirir. Nitekim "Allah’ım, Sen (isim) yaşadıklarıyla ilgili hissettiklerini bilirsin” ya da "(isim) yanına çabuk erişebilme arzusunu dile getirdi. (İsim) arzusunu işit” ya da “(isim) sana uzak oğlundan (oğulun ismi)

104 Kirkwood, Pastoral Care in Hospitals, s. 110.

105 Kirkwood, Pastoral Care in Hospitals, s. 110. 
bahsediyordu. (İsim) oğlunun, eşinin (isim) ve onların çocuklarını koru Allah’ım” gibi dua örnekleri bu bağlamda zikredilebilir. Duada vurgu hastanın konuşurken vurguladığı şeyde olmalıdır. Hastanın düşüncelerinin Tanrıłya tam olarak aktarılması sizin onu dinlediğinizi, anladığınızı, hastanın duygularını onayladığınızı, bu duyguları paylaştığınızı, hasta ile içten alakadar olduğunuzu, empati yaptığınızı, manevi bakımı hakikaten sergilediğinizi kanıtlar. ${ }^{106}$

Dua ederken olmayan bir şey hastanın aklına sokulmamalıdır. Bazen duayı hastanın ve yakınlarının yanlış bilgi ve düşüncelerini düzeltmek için bir araç olarak gören kişiler hastanın itikadı ve duygularıyla aynı fikirde olmayan tarzda dua edebilmektedir. Hastane hastaların yanlış inançlarını düzeltme ya da din propagandası yapma yeri değildir. Aksine burada öncelik hasta ve hastanın ihtiyaçlarıdır. Reddedilmeyi davet etmek ve tansiyonu artırmak için en kolay yol aynı fikirde olmadığı bir duayı hastanın onaylamasını beklemektir. ${ }^{107}$

Duada dikkat edilmesi gereken bir diğer unsur dua ederken dinî jargon kullanmamaktır. Yatağın başucunda yapılan duanın basit, sade ve anlaşılır bir dilde olması gerekir. Önceki nesillerin dinî jargonları anlaşılır değildir. Basit günlük konuşma dili sizi hasta ile aynı seviyeye indirir. Günlükdil kullanarak kabul edilebilir bir gerçeklikve anlam havası oluşturulur. ${ }^{108}$

Dua ederken Tanrı’nın merhameti de hatırlatılmalıdır. Hastanın başucunda edilen duanın pek çok boyutu vardır. Hastanın duygularını Tanrı’ya sunar böylece hasta duygularının sunulmuş olmasından dolayı bir rahatlama duygusu elde ederler. Ancak bu yeterli değildir. Hastalar Tanrı̉nın ilgisinin, sevgisinin ve merhametinin kendileri için de mevcut olduğunu hissetmeye ihtiyaç duyarlar. Teşhis, test, ameliyat, psikiyatrik bir ilaç ya da radyolojik bir tedavinin bulutlandırdığı bir hasta için seven bir Tanrı tarafından gözlendiğini bilmek bir hastanın erişebileceği en büyük rahatlık ve güvencedir. Dua doktor ve çalışanlara referansı da ihtiva ettiğinde dua takviye edilmiş olur. Merhametli bir Tanrı̉nın mevcut olduğunun şuurunu yaratmak yatak başında yapılan duanın temel amacıdır. ${ }^{109}$

Duada hasta umutlu olmaya teşvik edilmelidir. Umutsuz bir kişi terkedilmişlik duygularına boğulur. Durumları genellikle çok hızlı bir şekilde kötüye gider. Acı ve fiziksel üzüntü yoğunlaşır. Hasta daha da kabuğuna çekilir. Manevi danışman kendi dindar, sağlıklı varlığı ile neredeyse bu hastalarla dalga geçer gibi görünür. Dua umut aşılarken dürüst olmalı, boş umut aşılamamalıdır. Paul Iron, kendisine sayılı günleri kaldığı bildirilen bir hasta için umudun ağr kesicilerle, çalışanlarla, akraba ve arkadaşlarla geçirilecek iyi günlere yönlendirilebileceğini, kişinin dinî bağlarının derinleştirilmesinin de bunun tamamlayıcısı olduğunu belirtir. ${ }^{110}$

\footnotetext{
106 Kirkwood, Pastoral Care in Hospitals, s. 111.

107 Kirkwood, Pastoral Care in Hospitals, s. 111.

108 Kirkwood, Pastoral Care in Hospitals, s. 111-112.

109 Kirkwood, Pastoral Care in Hospitals, s. 112.

110 Kirkwood, Pastoral Care in Hospitals, s. 112.
} 
Duada bir başka husus manevi danışmanın kullandığ kelime ve bilgiye dikkat etmesidir. Hastane çalışanlarının verdiği bilgi açığa vurulmamalıdır. Bakım hastanın durumunu yanlış yorumlama veya abartmamakla uygulanmalıdır. Dua ile moral bozucu izlenimler iletilebilir. Örneğin “Tanrı’nın inayetinde olmak” gibi ifadeleri çok fazla kullanmak gibi. Hasta belki de kendi durumunun ciddiyetini reddediyor olabilir ya da ölümü düşünmeyi akla getirecek herhangi bir şey ya da neden olmayabilir. Duada ebedi huzur ve inayetten ya da cennet beklentisinden bahsetmek akrabalarda ve hastada çalışanların çaresiz kaldığı düşüncesine, depresyona ve çalışanlara karşı güvenlerinin sarsılmasına neden olabilir. Akrabalar hastanın gerçek durumunun kendilerinden saklandığını düşünebilirler. Manevi danışmanın duasını müteakiben hastalar hayatta kalma arzularını yitirebilirler. Bu durum idaresi zor bir probleme dönüşürebilir ve yavaş yavaş tıbbî olarak açık bir nedeni olmaksızın gerilemeye başlayabilirler. ${ }^{111}$

Dualar çıkarcı olmamalıdır. Bazı manevi danışmanlar için hastanın ölmeden evvel "Tanrı ile ilişkisini düzelttiğini görmek" duanın motivi haline gelir. Dua hastanın tevbe etmesi ve Tanrı’ya bağlılığını itiraf etmesini sağlamak için pragmatik bir aparata dönüşebilir. Bu durum dürüst ve ahlaki değildir. Hasta üzerindeki etkisi ise düşmanlığ 1 artırmaktan ibarettir. Özellikle kardiak hastası için bu durum stres seviyesini artırıp kan basıncını yükseltebilir, böylece vaktinden önce ölümcül bir epizota zemin hazırlayabilir. ${ }^{112}$

Pek çok durumda hastanın dinî bağlantısı, dinî fiilleri ya da duygularına dair bilgi edinemeyebiliriz. Dua da talep edilmeyebilir. Bu durumlarda örneğin hastanın ellerine ya da omuzlarına dokunarak “Tanrı seninle olsun" ya da "Tanrı seni korusun” tarzında bir ifade ile hastanın yanından ayrılmak uygun olabilir. ${ }^{113}$

İnsanların genellikle nasıl dua ettikleri keşfedilmelidir. Hastalar normal şartlarda nasıl dua ediyor ise hastane ortamında da aynı șekilde dua etmek onların kendilerini daha rahat hissetmelerini sağlar. En sık dua etme şekli karşılıklı konuşma şeklinde yapılan duadır. Ayrıca dua etmeden önce hastadan ya da yakınlarından izin alınmalıdır. Dua talebi hastadan gelmelidir ya da hastanın dua edilmesiyle ilgilendiğini gösteren işaretler takip edilmeli, sonra hastaya sorulmalıdır. ${ }^{114}$ İnsanların genellikle karşılıklı konuşma tarzında spontane duaları tercih ettiği çalışmalarla tespit edilmiş olsa da manevi danışman tefekkür duası ve ritüel duaların da farkında olmalıdır. Bu tarz dualar da hasta için son derece huzur verici olabilir. Manevi danışman hastanın haline, kişiliğine, kişilerin karakter özelliklerine uygun duaları seçerse beklenilen etki optimize edilmiş olur. Örneğin dışadönük sosyal bir kişi konuşma tarzında, içe dönük kişi ise sessiz, tefekkür duasını tercih edebilir. ${ }^{115}$

111 Kirkwood, Pastoral Care in Hospitals, s. 113.

112 Kirkwood, Pastoral Care in Hospitals, s. 113.

113 Kirkwood, Pastoral Care in Hospitals, s. 114.

114 Silton-v.dgr., "Pray Tell: The Who, What, Why, and How of Prayer Across Multiple Faiths", s. 48; Winslow-Winslow, "Examining the Ethics of Praying With Patients", s. 173; Cohen-v.dgr., "Prayer as Therapy", s. 46.

115 Taylor, "Prayer's Clinical Issues and Implications", s. 180-181. 
Eğer karşılıklı konuşma tarzında dua etme tercihinde bulunuldu ise bu durumda hastanın ne için dua etmek istediğini öğrenmek faydalı olur. Bunu öğrenmek için "özellikle dua etmemi istediğiniz bir şey var mı?” sorusunun yanıtı hastanın ne için endişelendiği ya da külfet duyduğunu belirleyecektir. Yapılan bir çalışmada Amerikalı Hıristiyanların en sık yol gösterme, iyileşme, şükran, kendisi ve başkaları için korunma duası ettiklerini ortaya koymuştur. ${ }^{116}$ Türkiye'de yapılan bir alan araştırmasında ise katılımcıların çoğunlukla şifa, sıkıntılarla mücadele edecek güç, bereketli kazanç, bol rızık, huzur, mutluluk, affedilmek, Allah’ın rızasını kazanmak, dünya ve ahiret hayatında güzellik, başarı için Allah’a dua ettikleri tespit edilmiştir. ${ }^{117}$

Eğer manevi danışman hastayı yeterince dikkatli dinledi ise bu durumda ne için dua etmeyi istediğinin sorulmasına gerek kalmaz. Çünkü hastanın hikayesinde gizli ve açık ipuçları mevcuttur. Hastaların ihtiyaçları genellikle, reddetme (“Tanrım, bu benim başıma gelemez!”), duygusal boşalım (“Tanrım, korkuyorum!”), depresyon, soyutlanmışlık ya da kendi kendine acıma ("Hiç kimse anlamıyor!”), panik ya da anksiyete (“Artık dayanamıyorum!"), suçluluk (“ah keşke...”), olumsuzluk (“İstemezdim...”), sosyal paylaşma, umut, kabul ya da alıştırma ve entegrasyonla ilgili olmaktadır. Hastalarla sohbet esnasında bu tarz ihtiyaç duaları dinlemek manevi danışmanın içsel duyguları ifade eden spontene, günlük dilde dualar kompoze etmesine imkan verecektir. ${ }^{118}$

Taylor çalışmasında hastanın dua etmek isteyip istemediğinin ve nasıl dua etmek istediğinin belirlenmesi için bir ön değerlendirme yapılması gerektiğini öne sürer. Bu ön değerlendirme fazla zaman almamalıdır. Kısa bir evet-hayır sorusu bunun için yeterli olmalıdır. Örneğin: "Beraber dua etmek sizin için rahatlatıcı olur mu?", "Ne tür dua sizin için faydalı olur?” Bu iki soru hastanın dua etmek isteyip istemediğini, ne tür dua tercih ettiğini bulmak için yeterlidir. ${ }^{119}$ Yine Taylor çalışmasında manevi danışmanların hastanın taleplerini doğru değerlendirebilmeleri için yardımcı sorular formüle etmiştir. O, bu soruları şu şekilde tabloya aktarmıştır: 120

Tablo 1. Duanın Rolünü/Önemini Anlamak İçin Sorulabilecek Sorular

1. Yapılan çalışmalar pekçok kişinin hastalıkla başa çıkarken dua ettiklerini ortaya koymuştur. Durum sizin için de böyle midir?

2. Dua etmek sizin için önemli midir?

3. Dua etmenin size yararı dokunur mu?

\footnotetext{
116 Taylor, "Prayer's Clinical Issues and Implications", s. 182.

117 Pınar, Duanın Ruh Sağlı̆̆ Üzerindeki Etkileri, s. 77.

118 Taylor, "Prayer's Clinical Issues and Implications", s. 182.

119 Taylor, "Prayer's Clinical Issues and Implications", s. 181.

120 Taylor, "Prayer's Clinical Issues and Implications", s. 182.
} 
Tablo 2. Dua Tercihleri, Şekli ve Muhtevasını Anlamak İçin Sorulabilecek Sorular

\begin{tabular}{|ll|}
\hline 1. & Kime dua edersiniz? \\
\hline 2. & Ne tür dua etmek sizi rahatlatır? \\
\hline 3. & Ne için dua etmemi istersiniz? \\
\hline 4. & Sizin için nasıl dua etmemi istersiniz? \\
\hline 5. & Dua ederken size faydası dokunan/ya da dua etmenizi engelleyen şey nedir? \\
\hline 6. & $\begin{array}{l}\text { Ne tür dua tecrübesi sizin kendinîzi Tanrı’ya (ya da hasta Mutlak ya da Kutsal Kaynağa nasıl atıfta bulunuyor ise) } \\
\text { daha yakın hissetmenize yardımcı olur? }\end{array}$ \\
\hline
\end{tabular}

Tablo 3. Hastalığın Dua Etmeyi Zorlaştırması

1. Hastalığınız dua etme şeklinizi nasıl etkiledi? Ya da dua ile ilgili düşünme şeklinizi nasıl etkiledi?

2. Hastalandığınızdan beri dualarınız değiști mi?

3. Bazen dua etmek zor gelir mi? Bununla nasıl başa çıkıyorsunuz?

4. Çok ciddi hastalı̆̆ı olan kişiler hastalıklarının dua ile ilgili inançlarını tekrar gözden geçirmelerine neden olduğunu anlatırlar. Bu sizin başınıza da geldi mi?

5. Hastalık dua ile ilgili inançlarınızı değiştirdi ya da sorun oluşturdu mu?

6. Dua etmek inanç sahibi olmayı gerektirir. İnanç ise şüphe barındırır. (Şüphe kişi inanmayı tercih etmeden önce mevcut olmalıdır.) Hastalığını şüphe duyma ile inanma arasındaki bu hassas dengeyi nasıl etkiledi?

7. Bunun gibi dönemlerde bazı kişiler dualarının kabul edilip edilmediğini ve nasıl "yanıtlandığını" merak etmeye başlarlar. Bu konuda sen ne düşünüyorsun?

Tablo 3’teki sorular hastanın manevi şüpheleri olup olmadığını değerlendirmek amacıyla kullanılabilecek sorulardır. Sorular duygulardan ziyade düşüncelere yoğunlaşmıştır. Manevi stresin işaretleri hastanın hastalıkla ilgili dua anlatımlarında gizlidir. Ancak bu çelişkilerin manevi danışmana anlatılmasını bir kenara bırakın, kişisel olarak farkına varılması bile haddinden fazla acı vericidir. Konu hassas olduğu için soruları kullanılırken azami derecede dikkat etmelidir. Hastanın manevi stres yaşadığının göstergesi, manevi danışmana yöneltilmiş bir takım sorularda mevcuttur. Konsantre olamamaktan şikayet etme, çok hasta olduğunda nasıl dua edeceğini bilememe, doğru şekilde dua edip etmediğinden endişe duyma, Tanrı’nın duaları yanıtlayıp yanıtlamadığını merak etme, Tanrı’nın varlığından şüphe duyma ve bunları ifade etme manevi strese işaret edebilir. 


\subsection{Konsantre Olamıyorum Nasıl Dua Edebilirim?}

Hastalığın fiziksel ve ruhsal olarak bireyi olumsuz yönde etkilediğini yukarıda görmüştük. Bu nedenle hastaların dua ederken konsantrasyon problemi yaşamaları oldukça doğaldır. Aldıkları ilaçlar, ağrılar, fiziksel olarak yetersiz oluşları, hastane ortamı konsantrasyon problemine neden olabildiği gibi ölüm düşüncesi, endişe ve korkular da hastanın konsantrasyonunu bozar. Bu durumda danışman dua etmek isteyen ve konsantre olamamaktan şikayet eden bir hastaya nasıl destek olmalıdır? Bunun yanıtını Taylor'ın çalışmasından ${ }^{121}$ yararlanarak arıyacağız. Normal şartlarda kişilerin konsantre olmaya çalıştıklarında düşüncelerinin başıboş dolanıp durması normaldir. Ancak ciddi hastalıklar dikkatin de zayıflamasına neden olur. Konsantre olamamanın nedeni eğer rahatsız edilme ya da başı boş dolaşan düşünceler ise, manevi danışman hastayı dua ederken karşılaştığı bu bölünmeleri dua etmek için bir başlangıç noktası olarak görmeye teşvik edebilir. Örneğin ölüm düşüncesi hastanın dualarını bölüyor ise hasta ölümle ilgili bu korkuları konusunda dua etmeye teşvik edilebilir. Hastalar için kutsal sesler (ilahi kitaptan pasajlar dinlemek, ezan sesi gibi) veya dinî müzik dinlemek, yazmak ya da sanatsal bir şekilde yaratıcı dualar ya da Tanrı'ya olan niyetlerini bazı beden hareketleri ya da duruşlarıyla (dua ederken alınan belli tavırlar) ifade etmek faydalı olabilir. Sesli mantra ${ }^{122}$, görsel yantra ${ }^{123}$ ya da dua tesbihleri gibi nesneler kullanmak dua esnasında konsantrasyonu sağlamaya yardımcı olur. Eğer konsantre olamamanın nedeni genel bir enerjisizlik, depresyon ya da baş dönmesi gibi durumlar ise hasta Tanrı'nın varlığının bilincinde olabilmesi için imgelem kullanmaya yönlendirilebilir. Örneğin, gün ışığını Tanrı'nın rahmeti olarak hayal etmek dua olacaktır. Bu tarz bir hasta için konuşma tarzında edilen dua sinir bozucu olabilir, tefekkür (meditasyonel) duası daha rahatlatıcıdır. Başkalarının da onlar için dua ettiklerini hatırlatmak faydalıdır.

\section{2. Çok Hasta Olduğumda Nasıl Dua Ederim?}

Yukarıdaki tavsiyeler bu durum için de kullanılabilir. İlaveten hastaya duanın gerçek anlamı hatırlatılabilir. Dua “Tanrı ile karşılaşmak” olarak düşünüldüğünde, hastanın mevcut durumda şükredebileceği, Tanrı’nın varlığını hissedebileceği çeşitli durumları fark etmesi sağlanmalıdır. Akut stres durumlarında dua süresince yinelenebilecek kısa ritüel dualar oldukça faydalıdır. Bu tür ritüel duaların örnekleri “Tanrı benim çobanımdır (The Lord is my

121 Taylor, "Prayer's Clinical Issues and Implications", s. 183.

122 Mantra: Hinduizm ve Budizmde mistik ya da spiritüel etkisi olduğu düşünülen kutsal seslerdir (hece, kelime ya da ayetlerdir). Mantralar sesli olarak ya da kişinin ağzının içinde içsel bir şekilde seslendirilir. Belirli bir süre sürekli seslendirilebildiği gibi, yalnızca bir kez de söylenebilir. Çoğu mantranın kayda değer bir anlamı mevcut değildir. Ancak derin anlamları olduğu ve manevi irfanı damıtma etkisine sahip olduğu düşünülür. Bu nedenle belirli bir mantranın yinelenmesi ya da meditasyonda kullanılması uygulayıcıda trans benzeri bir durum ortaya çıkarır ve kişiyi üstün bir manevi farkındalık seviyesine yükseltir.

123 Yantra: (Sanskritçe "alet"). Tantrik Hinduizmde ve Vajrayana ya da Tantrik Budizmde ritüeli destekleyici olarak kullanılan doğrusal bir diyagramdır. Yantranın daha ayrıntılı ve resimsel şekli mandala olarak isimlendirilir. Yantraların, yere ya da kağıda çizilip ritüel bittikten sonra silinenlerinden, tapınaklardaki gibi taş ya da metale oyulmuş olanlarına kadar çok çeşitli formları mevcuttur. 
shepherd), Yahudilerin "Şema”sı (İşit ey İsrail: Ebedi olan bizim Tanrı'mızdır, sadece ebedi olan), Mesih İsa duası (İsa Mesih, Tanrı’nın Oğlu, Bana merhamet et, bir günahkara), İslâmi “Tevhid” (Lâ ilâhe illallâh) ve Doğu kaynaklı mantra “om”. Pek tabii ki hangi ritüel duanın kendisine rahatlık vereceğine karar vermek hastanın bilebileceği bir şeydir. Kişisel olarak bir anlam ifade eden ritüel dua zorunludur. Pozitif bir şekilde ifade edilmiş bir dua muhtemelen en iyi seçenektir (örneğin "İsa beni sev" yerine "İsa beni sever" gibi). Yineleyen ritüel duanın, kendi kendinî hipnozdaki gibi, aynı rahatlatıcı etkiyi yaratabileceğine inanılmaktadır. ${ }^{124}$ Ron Delbene ${ }^{125}$ ciddi hastalar için kullanılabilecek "nefes duasından" bahseder. Bu metotta ihtiyacı ifade eden bir kelime ya da ifade ile birlikte Tanrı'nın meşhur bir ismi seçilir. Bu ikisi bir cümlede birleştirilir ve gün boyunca tekrar edilir. Bu hastaya büyük bir rahatlama ve güç kaynağı sağlar. Şunlar bu tarz duaya örnek olabilir: "Ey kurtarıcım, acılarımı azalt", "Bana yakın ol, ey seven Tanrı", "Merhametli İsa, ruhuma ve bedenime dokun", “Aziz Baba, beni huzurla doldur”. Hastalar bu duaya gün boyunca ya da günlerce devam edebilirler.

Manevi danışman hastaya "hastalığın dua ile ilgili inançlarının değişmesinde yardımı dokunmuş olabilir mi?” şeklinde bir soru sorarak onu hastalığının duaya etkisini olumlu bir şekilde ifade etmeye teşvik edebilir. Hastaya "Fizikî acının kendilerinin Tanrı değil ölümlü olduklarını ve Tanrı'ya ihtiyaç duyduklarını hatırlattı̆̆ı” anımsatılabilir. Hastalık bizleri Tanrı’ya yakınlaştırdığı, yine hastalığın Tanrı’yı tanımanın yeni yollarını bulma konusunda yardımcı olduğu da belirtilebilir. ${ }^{126}$ Ayrıca hastaya aslında hastalığın dünyanın günlük koşuşturmasından bir mola alarak Tanrı’yı hatırlama ve hastanın Tanrı ile ilişkisini düzene koyması için bir firsat olarak algılanabileceği de salık verilebilir.

\subsection{Doğru Şekilde mi Dua Ediyorum?}

Böyle bir soru, soran kişinin zararlı bazı inançları olduğuna işaret edebilir. Sorunun temelinde "kişinin Tanrı ile yanlış bir şekilde de karşılaşılabileceği” varsayımı yatar. Kişi muhtemelen cezalandırıcı, koşullu seven bir Tanrı’ya inanmaktadır. Bu tarz bir inanca sahip olan hasta "Dua nedir?”, "Dua merhametli bir Tanrı'ya yanıt mıdır?", "Nihai Öteki’nin, bir seviyede, farkında olmak mıdır?", "İstediğimizi yaptırmak için Tanrı ile güreşmek ya da onu manipüle etmek midir?", "Dua etmek kurallar olmaksızın konuşmayı ya da var olmayı mı gerektirir ya da duaya uygulanan belirli kurallar mı vardır?" ve benzeri sorularla hasta dua hakkındaki inançlarını yeniden gözden geçirmeye teşvik edilebilir. Taylor kadınlar arasında sık karşılaşılan bir düşünceye işaret eder. Buna göre insan kendisi için dua etmemelidir çünkü "bu bencillik olur". Böyle bir durumda duanın ne olduğunun ve manevi liderlerin ya da peygamberlerin de tarihte kendileri için dua ettiklerinin hatırlatılması hastaya kendileri için dua etme noktasında "müsaade" verecektir. ${ }^{127}$

124 Taylor, "Prayer's Clinical Issues and Implications”, s. 183-184.

125 Kirkwood, Pastoral Care in Hospitals, s. 114.

126 Taylor, "Prayer's Clinical Issues and Implications", s. 184.

127 Taylor, "Prayer's Clinical Issues and Implications", s. 184. 


\subsection{Tanrı Neden Sessiz? Tanrı Var mı?}

Bu soru hastaların yakarışları arzuladıkları şekilde sonuçlanmadığında (örneğin sihir talepleri işlemediğinde), Tanrı̉nın sessiz ya da yok olduğu neticesine ulaştıklarında dillendirilir. Capps ${ }^{128} 1950$ 'de gerçekleştirilen deneysel bir çalışmaya atıfta bulunarak dua eden insanların çoğunun, Tanrı’nın dualarını işittiğine ve yanıtladığına inandıklarını belirtir. Ancak dualar her zaman bireylerin istediği şekilde neticelenmeyebilir. Tanrı, dua tecrübesinin etkili bir boyutu olmadığında "yok" olarak tecrübe edilir. Her ne kadar hastanın bu çıkarımları üzerinde düşünmesini sağlamak için Sokratçı sorular kullanmak faydalı olsa da, öncelikle danışmanın bu konularla alakalı "öz-farkındalığa" ${ }^{129}$ sahip olması gerekir. Ancak kendi içinde bu ve benzeri soruları kendisi adına yanıtlamış bir danışmanın bir başkasına yardımcı olması fayda sağlayacaktır. Taylor ${ }^{130}$ bu tarz soruları şu şekilde formüle eder: "Bu karanlık dönemlerden evvel Tanrı nasıldı?”, "Değişen sen misin yoksa Tanrı mı?”, “Tanrı’nın varlı̆̆ını sorgulamamıza neden olan zor zamanlar hakkında ne düşünüyorsun?”.

Tanrı̉ın sessizliği ya da yokluğu ile ilgili sorular bir manevi danışmanın konuşmadan kaçmasına neden olmamalıdır. Bu sorular kişinin manevi inançlarına meydan okur. Bu tür sorular şu ve benzeri sorular üzerinde düşünmek suretiyle dikkatle gözden geçirilmelidir:

a. Acaba "sessizlik" bizim kendi sağırlığımız mı? Bu "büyük bir tereddüt (pause) olabilir mi? Bu sessizliği başka bir şekilde yorumlamak mümkün mü?

b. Seni sessizlik olduğu neticesine iten şey nedir? Tanrı̉nın seninle iletişim kurmuş olabileceği başka yollar da olabilir mi?

c. Geçmişte sana Tanrı̉nın mevcut olduğunu doğrulayan ne idi? Geçmişte sana göre Tanrı’nın sesi neye benziyordu? Hayatta bu senin için nasıl bir değişiklik gösterdi? Hastalıkla yaşamak Tanrı ile senin birbirinizle iletişim kurmanızı nasıl değiştirdi? Eğer uygun ise hastaya, manevi liderlerin yüzyıllar boyunca Tanrı’yı çeşitli vasıtalarla konuşur olarak anladıklarını hatırlatmak faydalı olabilir. Tabiat, insanlar, kutsal yazımlar ve içimizdeki "vicdanın sesi" kişilerin Tanrı ile karşılaşmalarına imkan sağlayabilir. ${ }^{131}$

Levine ${ }^{132}$ çalışmasında yanıtlanmayan duaların inancın zayıflamasına ve hatta inanç kaybına neden olabileceğini belirtir. İnanç kaybı ise kişisel bir krizdir. Duaların yanıtsız kalmasını rasyonelleştirmek ve uyumsuzluğu indirgemek yoluyla inancı korumaya yarayan bilişsel yollar ve sosyal baskı unsurları mevcuttur. Toplumda pekçok kişi dua eder ve neticesini gördüğünü belirtir. Bu genel bir kabuldür. Sosyal çevremizde defalarca yinelenen bu tarz olumlu referanslar, bireyin duaları karşılıksız kalsa da duadan vaz geçmesini önler. Bilişsel

\footnotetext{
128 Capps, "İstek Duası (Petitionary Prayer) Psikolojisi”, s. 162.

129 Winslow-Winslow, "Examining the Ethics of Praying With Patients", s. 175-176.

130 Taylor, "Prayer's Clinical Issues and Implications", s. 184.

131 Taylor, "Prayer's Clinical Issues and Implications", s. 184.

132 Levine, "Prayer as Coping", s. 92.
} 
yollar da duaya yanıt almaktaki başarısızlığın farkına varılmasını engeller. Duanın yanıtı gibi görülebilecek olası bir tesadüf bir başarı olarak kabul edilir böylece duanın etkinliğine olan inanç güçlenir. Hoşa giden olaylar hatırlanıp gitmeyenler unutulduğunda "yanıltıcı bir korelasyon" yaratırlar. Zorluklar Tanrı’nın bir denemesi, üstesinden gelinebilecek bir imkan olarak görülür. Çünkü Tanrı taşıyamayacağı bir yükü insana yüklemez. Aynı şekilde duadan beklenen sonucun elde edilememesi yetersiz inanca, dolayısıyla da "dua edene" atfedilir. ${ }^{133}$ Böylece bilişsel yollar ve sosyal baskı duadan bekelenen neticenin alınmaması nedeniyle oluşan durumu ortadan kaldırarak kişilerin inanç kaybı gibi bir krize kapılmalarını engeller.

\section{Duayı Manevi Danışmanlıkta Destekleme Metodu Olarak Kullanmanın Riskleri}

Son dönem tıp anlayışı, hastaları sadece bozuk fiziksel yapılar olarak değil beden ve ruhtan oluşan bir bütün olarak algılama ve tedavilerinde bir bütün olarak bu özelliklerine de hassasiyet gösterilmesi yönünde evrilmiştir. "Hastanın mahremiyetinin, özerkliğinin ve refahının bilinçli din propagandası ya da kasıtsız baskı ile çiğnenebileceği riski”" ${ }^{134}$ hastaların dinî inançlarının sorulmasını zorunlu kılar. Ancak hastanın dinî eğilimlerini bilmek ve bunları tedavinin bir parçası olarak kullanmak da beraberinde bazı tehlikeler getirir. Hastalığ nedeniyle zayıf, korunmasız ve başkalarının bakımına muhtaç olan hastalar inançlarının suistimal edilmesi, başka dinî inançların kendisine empoze edilmeye çalışılması ya da "kendilerine sunulan tedavinin kalitesinin belli bazı dinî bağllılıları kabul edip etmemelerine göre değişebileceği’ ${ }^{135}$ gibi tehlikelere maruz kalabilir. Bu durumda bir danışman duayı destekleyici bir araç olarak kullanırken nelere dikkat etmelidir?

Manevi istismara neden olmasa da hasta ile dua ederken faydasız olabilecek yaygın bazı görünmez tehlikeler mevcuttur. Manevi danışman, duayı, hasta ile daha derin sohbet edebilmek ve onunla terapötik bir ilişki kurabilmek için bir atlama tahtası olarak kullanmalıdır. Ancak dua acının ifade edilmesini engellemenin bir yolu olarak kullanıldığında amacı dışında kullanılmış olur. Aslında "hastanın istediği yalnızca danışmanın kendisini dinlemesi ya da hastayla birlikte olması iken hastalar yatıştııılamaz acılarını dillendirmeye başladıklarında hastayı rahatlatamamanın verdiği öfke ile danışman hastaya dua etme teklifinde bulunabilir". ${ }^{136}$ Ross ${ }^{137}$ duanın "kolay tamir edici" bir yöntem olarak görülmesine karşıdır. Ona göre dua "zor ilişkilerden, mütecaviz düşüncelerden ve rahatsız edici duygulardan sakınmanın" bir yolu olarak kullanılır. Ancak dua "semavi bir arıza tamir servisi telefon hattıymış" gibi kullanıldığında, ciddiyyetsizce kullanılmış demektir.

133 Levine, "Prayer as Coping", s. 93.

134 Cohen-v.dgr., "Prayer as Therapy", s. 45.

135 Cohen-v.dgr., "Prayer as Therapy”, s. 45

136 Taylor, "Prayer's Clinical Issues and Implications”, s. 185.

137 Ross, Counselling Skills for Church and Faith Community Workers, s. 61. 
Bir manevi danışmanın kendi inancını hastaya empoze etmesi ya da hastanın inançlarına saygısız bir tutumla dua etmesi de uygun değildir. Aynı din içindeki farklı mezheplerde mevcut olan farklı inanç ve uygulamalar bile bize mezhepler üstü dua etmenin en güvenilir yol olduğunu gösterir. Örneğin çokkültürlü bir toplumda İsa Mesih'e, Buda'ya ya da Allah'a iltica etmek yerine Tanrı gibi daha kapsayıcı ve nötr bir ifade kullanmak daha uygundur. Spesifik bir netice için dua etmek yerine Tanrı'dan destek istemek ya da Tanrı'nın irade ettiklerini talep etmek bir diğer güvenli yöntemdir. ${ }^{138}$ Dua "sihir ricası" olarak kullanılmamalıdır. Dua ile sihri birbirinden ayıran tutum, “Tanrı’nın dilediği olacak” (inşaallah) ifadesinde gizlidir. ${ }^{139}$

Samimi ve etik kalmak için manevi danışman kendisinin ve hastanın ortak inançlarını yansıtacak bir halde dua etmelidir. Hasta ile danışmanın dua ediş tarzları ve yaklaşımları her ne kadar birbirinden farklı olsa da Tanrı ile karşılaşırken her ikisinin de paylaşabileceği ortak bir yaklaşım (birlikte geçirilebilecek sessizlik anı gibi) mutlaka mevcuttur. Duanın genel muhtevası farklı olabilse de Tanrı'ya yakın olma ihtiyacı, bağışlanma, huzur gibi temel manevi ihtiyaçlar farklı inançlara sahip hasta ve danışmanı duada birleştirebilir. ${ }^{140}$ Hasta ile danışman arasında inanç farklılığı olduğunda benimsenebilecek bir başka yöntem ise danışmanın dua etme eylemini "dinî bir eylem olarak değil hastanın manevi bir ihtiyacını karşılamak" ${ }^{141}$ şeklinde görmesidir. Ayrıca manevi danışman inanç farklılığından dolayı hastayla birlikte dua etme konusunda kendisini rahatsı hissederse bu durumda dua etme talebinde bulunan hastayı başka şekillerde destekleyebilir. Hastanın sessiz ve özel bir zaman ihtiyacına saygı duymak, ilaç ve tedavi zamanlarını hastanın bu özel zamanına göre ayarlamak, hastanın odasının kapısına odaya girilmemesini isteyen bir not asmak buna örnektir. Danışman, Müslüman hastaya abdest almasında ya da duadan önce İslâm'da gerekli olan yıkama eylemini gerçekleştirmesinde yardımcı olmak; hastanın dua kitabından ya da kutsal kitabından bir pasaj okumak; hastanın tesbihi, ibadet kıyafeti, yantrası ya da diğer ibadet nesnelerinin güvenliğini sağlamak suretiyle de dinî dua geleneklerini uygulama noktasında hastaya destek olabilir. ${ }^{142}$

Kendisini rahat hissetmese de hasta dua ederken sessizce yanında bulunarak hastaya eşlik edebilir. ${ }^{143}$ Dinî literatür birlikte yapılan duanın daha etkili olacağını söyler. Birlikte dua etmek hem danışman hem de hasta açısından anlamlı potansiyel bir tecrübeye imkan tanır. ${ }^{144}$ Dua etmeyi teklif etmek ("sana dua edeceğim" ya da "dualarımda olacaksın") hasta bir kişiye söylendiğinde hem teklif edilenin hem de edenin üzerinde psikolojik etki yaratır. Üzüntü

\footnotetext{
138 Kwiatkowski-v.dgr., "Physicians and Prayer Requests", s. 1259-1260.

139 Taylor, "Prayer's Clinical Issues and Implications", s. 185.

140 Taylor, "Prayer's Clinical Issues and Implications”, s. 186-187.

141 Winslow-Winslow, "Examining the Ethics of Praying With Patients", s. 173; Murray, "Prayer as Coping”, s. 55.

142 Taylor, "Prayer's Clinical Issues and Implications", s. 186; Hollywell, "Private Prayer as a Suitable Intervention for Hospitalized Patients", s. 649.

143 Winslow-Winslow, "Examining the Ethics of Praying With Patients", s. 176.

144 Taylor, "Prayer's Clinical Issues and Implications", s. 185.
} 
işareti ya da yardım çığlığı, işiten kişide yanıtlamak için evrimsel temelli bir arzu uyandırır. Akabinde dua etmeyi teklif etmek ihtiyaç içindeki kişiye duygusal desteği ifade eder ve ihtiyaç karşısında dua etmeyi teklif eden kişinin çaresizliğini yatıştırır. ${ }^{145}$ Hasta ile birlikte dua etme konusunda kendilerini rahat hissetmeyen bazı danışmanlar hastalara özel olarak dua etmeyi tercih ederler. Bir hasta için arkadaşlarının, ailelerinin ve hatta yabancıların kendileri için dua ediyor olduklarını bilmek oldukça rahatlatıcıdır. Dolayısıyla hasta ve hasta yakınlarının danışmanın "sizin için dua deceğim" demesini çok olumlu karşılamaları şaşırılacak bir durum değildir. ${ }^{146}$

Manevi danışmanların zararlı dua inanç ve uygulamalarına sahip hastalarla karşılaşması mümkündür. Örneğin "eğer yeterince sıkı dua edersem iyileștirileceğine" inanmak ya da dua ederken transa benzer bir hal yakalamak için halüsinasyon yapan ilaçlar kullanmak Batıll, geleneksel tıp anlayışıyla çelişir. Bu durumda manevi danışman hastanın dua "modeli"ni değerlendirmelidir. Yani "Hasta duanın nasıl işlediğine inanıyor?", "Ona göre duayı etkili kılan şey nedir?", "Ona göre dua insan ile ilah ilişkisini nasıl yansıtır?", "Hastanın Tanrı tasavvuru nasıldır?” gibi soruların cevapları belirlenmelidir. Manevi danışman hasta ile tartışmak ya da ona gizlice mantıksız veya uygunsuz inanç şekillerini göstermeye çalışmak yerine, (tabîki hastanın izni ile) kendi dua etme "modelini” açıklayabilir. Danışman ve hasta bu iki modeli açıkça karşılaştırabilirler. ${ }^{147}$

Dua, dinî bağları güçlendirme işlevini, en iyi, manevi danışman ile hasta aynı dinî bağları paylaşıtı̆ında görür. ${ }^{148}$ Ancak dua inançları ve davranışları manevi danışmanın inançlarından farklı olan kişilere nasıl bakım sağlanacağı düşünüldüğünde danışmanın, hastanın faydalı olan (farklı da olsa) dua inançlarını ve uygulamalarını desteklemesi, faydalı ya da zararlı olmayan dua inanç ve uygulamaları için imkan sağlaması, eğer mümkün ise altta yatan inanç sistemini değiştirmeye çalışmaksızın zararlı inanç ve uygulamaları değiştirmesi ve hastaya alternatifler sunması beklenir. Zararlı inançların değiştirilmesi noktasında aile üyeleri ve hastanın din görevlisi terapötik müttefik olarak devreye sokulabilir. ${ }^{149}$ Danışman manevi uygulamaları önermemeli ya da hastaları başka dinî inançları benimsemeye zorlamamalı ve hastanın kendi manevi inanç ya da uygulamalarından vazgeçmeleri için baskı yapmamalıdır. ${ }^{150} \mathrm{Bu}$ kuralın birinci kısmı bazı danışmanlara zor gelebilse de hastane ortamı din propagandası yapma yeri değildir. Danışmanın rolü de bu değildir.

Hastanın manevi bakımını önemseyen manevi danışmanlar öncelikle kendi "manevi öz-farkındalıklarını” ${ }^{151}$ geliştirmelidirler. Kendisinin manen zayıf ve güçlü yönlerini bilmek

\footnotetext{
145 Levine, "Prayer as Coping", s. 87.

146 Taylor, "Prayer's Clinical Issues and Implications", s. 185.

147 Taylor, "Prayer's Clinical Issues and Implications", s. 186.

148 Silton ve ark., "Pray Tell: The Who, What, Why, and How of Prayer Across Multiple Faiths", s. 42.

149 Taylor, "Prayer's Clinical Issues and Implications", s. 186.

150 Winslow-Winslow, "Examining the Ethics of Praying With Patients", s. 174.

151 Winslow-Winslow, "Examining the Ethics of Praying With Patients", s. 175-176.
} 
bir danışmana, hastalık gibi hayatın genel akışında kırılma yaratarak hastanın kendi manevi problemlerini gün yüzüne çıkaran bir dönemde daha etkili yardım sunmasını sağlar.

Manevi danışmanın hastaya bakım uygularken karşılaşabileceği durumlara açıklık getirmeye çalıştık. İnançların farklı olması durumunda dahi bir hastayı manen desteklemenin mümkün olduğunu gördük. Danışman uygulamaları esnasında karşılaşabileceği durumların farkında olmalı, hangi tür tutum ve davranışların hastanın haklarını çiğnemek anlamına geleceğini bilmelidir. Manevi öz-farkındalık danışmanın problemlere yaklaşımında ilk adım olmalı ve danışman kendisinin ilk ve en önemli görevinin hayatlarının bu kırılma dönemlerinde dinî kimliklerine bakmaksızın hastaları en üst düzeyde desteklemek olduğunu unutmamalıdır.

\section{Sonuç}

Çalışmamızın temel amacı ülkemizde 2015 yılı itibariyle uygulamaya giren manevi danışmanlığın temel destekleme metotlarından biri olan “dua”nın ne olduğu, türleri ve nasıl kullanılması gerektiği konusunda rehber olabilecek bilgiler sunmaktı. 1900’lü yılların başlarından itibaren Batı geleneğinde yaygın bir şekilde uygulanan ve davranış bilimlerinin verileriyle beslenerek günümüzdeki şekline erişen manevi bakım ve danışmanlık uygulaması, insanın bulunduğu hemen hemen her alanda onun manevi, dini ve duygusal ihtiyaçlarını gidermek için hizmet vermektedir. Bu uzun yılların tecrübesine dayanan zengin literatürün ülkemizde yeni uygulama alanı bulan manevi bakım ve rehberlik uygulamalarında faydalı olacağı düşünülmektedir. Makalemizin başında alıntıladığımız gibi "dua güçlü bir araçtır ve kullanırken dikkat gerektirir”. Özellikle hastane gibi kırılganlığın ve duygusallığın en üst seviyede yaşandığı bir mekânda böyle bir aracın kullanımı, bireysel hakların çiğnenmemesi, yanlış anlamalara sebep olunmaması ve uygulanan destekleme metodundan beklenen neticenin elde edilmesi açısından çok dikkat gerektirir. Bilgin ${ }^{152}$ dua edenin ruh halini şöyle dile getirir: "Çaresiz anlarda kişi, hangi çevreden olursa olsun, matematik bir sonuç beklemeksizin, bazı yönelişlerde bulunur. Belki der, bunca bilinmedik iş, çözülmedik muamma yok mu? Belki benim bilmediğim bazı güçler de vardır, bana yardımcı olur.” Manevi danışmanın görevi de hastaların bu arayışlarında onları ve yakınlarını doğru şekilde destekleyebilmek için gerekli donanıma sahip olmaktır.

152 Bilgin, "Dua”, s. 69. 


\section{Kaynaklar}

Ai-v.dgr.: Amy L. Ai, Paul Wink, Terrence N. Tice, Steven F. Bolling, Marshal Shearer, "Prayer And Reverence In Naturalistic, Aesthetic, And Socio-Moral Contexts Predicted Fewer Complications Following Coronary Artery Bypass", Journal of Behavioral Medicine, 2009, XXXII, s. 570-581.

Alling, Frederic A. "Healing Effects of Belief in Medical Practices and Spirituality", Explore, 2015, XI sy. 4, s. $273-280$.

Altaş, Nurullah, "Hastanelerde Dinî Danışmanlık Hizmetleri (Türkiye Uygulaması Üzerine Deneysel Bir Araştırma)", Ankara Üniversitesi İlahiyat Fakültesi Dergisi, 1999, XXXIX, sy. 1, s. 599-659.

Andersson, Gerhard, “Chronic Pain and Praying to a Higher Power: Useful or Useless?” Journal of Religion and Health, 2008, XLVII, sy. 2, s. 176-187.

Argyle, Michael, "İbadet ve Dua" (trc. Mustafa Koç), Erciyes Üniversitesi Sosyal Bilimler Enstitüsü Dergisi, 2006, II, sy. 26, s. 317-338.

Aydemir, Abdullah, “Tedavide Duanın Yeri”, İslâm Medeniyeti, 1973, III, sy. 32, s. 7-16.

Ayten, Ali, Tanrıya Sığınmak Dini Başa Çıkma Üzerine Psiko-Sosyal Bir Araştırma, İstanbul: İz yayıncılık, 2012.

Bernardi-v.dgr.: Luciano Bernardi, Peter Sleight, Gabriele Bandinelli, Simone Cencetti, Lamberto Fattorini, Johanna Wdowczyc-Szulc, Alfonso Lagi, "Effect of Rosary Prayer Yoga Mantras on Autonomic CardioVascular Rhythms: Comparative Study", British Medical Journal, 2001, CCCXXIII, sy. 7327, s. 1446-1450.

Bilgin, Beyza, “Dua”, İslâm İlimleri Enstitüsü Dergisi, 1975, sy. 2, s. 67-70.

Breslin-Lewis: Michael Breslin and Christopher Alan Lewis, "Theoretical Models of the Nature of Prayer and Health: A Review", Mental Health, Religion \& Culture, 2008, XI, sy. 1, s. 9-21.

Capps, Donald, "İstek Duası (Petitionary Prayer) Psikolojisi” (trc. Ümit Horozcu), İstanbul Üniversitesi İlahiyat Fakültesi Dergisi, 2005, sy. 12, s. 157-169.

Cilac1, Osman, “Dua”, DİA, İstanbul 1994, IX, 529-530.

Cohen-v.dgr.: Cynthia B. Cohen, Sondra E. Wheeler, David A, Scott, Barbara Springer Edwards, Patricia Lusk, and the Anglican Working Group in Bioethics, "Prayer as Therapy: A Callenge to Both Religious Belief and Professional Ethics", Hasting Center Report 30, 2000, sy. 3, s. 40-47.

Dezutter-v.dgr.: Jessie Dezutter, Amy Wachholtz, Jozef Corveleyn, "Prayer and Pain: The Mediating Role of Positive Re-Appraisal”, Journal of Behavioral Medicine, 2011, XXXIV, sy. 6, s. 542-549.

Dossey, Larry, "Prayer, Medicine, and Science: The New Dialogue", Journal of Health Care Chaplaincy, 1998, VII, sy. 1-2, s. 7-37

George, Juvenal, Is Prayer Beneficial: An Examination of Types of Prayer and Life Satisfaction in Adolescents (doktora tezi, 2014), Chicago.

Gibbons-v.dgr.: Graeme Gibbons, Andrew Retsas, Jaya Pınıkahana, "Describing What Chaplains Do in Hospitals”, The Journal of Pastoral Care, 1999, LIII, sy. 2, s. 201-207.

Gubi, Peter Madsen, "An Exploration of the Use Of Christian Prayer in Mainstream Counselling", British Journal of Guidance \& Counselling, 2001, XXIX, sy. 4, s. 425-434.

Haley-v.dgr.: Katherine C. Haley, Harold G. Koenig ve Bruce M. Bruchett, "Relationship between Private Religious Activity and Physical Functioning in Older Adults", Journal of Religion and Health, 2001, XL, sy. 2, s. 305-312.

Handzo-v.dgr:: George F. Handzo, Kevin J. Flannelly, Kathryn M. Murphy, John P. Bauman, Margaret Oettinger, Elaine Goodell, Yusuf H. Hasan, David P. Barrie, Martha R.Jacobs, "What Do Chaplains 
Really Do? I. Visitation in the New York Chaplaincy Study", Journal of Health Care Chaplaincy, 2008, XIV, sy. 1, s. 20-38.

Handzo-v.dgr.: George F. Handzo, Kevin J. Flannelly, Taryn Kudler, Sarah L. Fogg, Stephen R. Harding, Yusuf H. Hasan, Meigs Ross, Bonita E. Taylor, "What Do Chaplains Really Do? II. Interventions in the New York Chaplaincy Study", Journal of Health Care Chaplaincy, 2008, XIV, sy. 1, s. 39-56.

Hollywell-Walker: Claire Hollywell and Jan Walker, "Private Prayer as a Suitable Intervention for Hospitalized Patients: A Critical Review of the Literature", Journal of Clinical Nursing, 2008, XVIII, sy.18, s. 637-651.

Horozcu, Ümit, Din Psikolojisi Açısından Dünyevi İstek Duaları (doktora tezi, 2010) İstanbul Üniversitesi SBE.

Johnson-v.dgr.: Mary E. Johnson, Ann M. Dose, Teri Britt Pipe, Wesley O. Petersen, Mashele Huschka, Mary M. Gallenberg, Prema Peethambaram, Jeff Sloan, Marlene H. Frost, "Centering Prayer for Women Receiving Chemotherapy for Recurrent Ovarian Cancer: A Pilot Study”, Oncology Nursing Forum, 2009, XXXVI, sy. 4, s. 421-428.

Kirkwood, Neville A., Pastoral Care in Hospitals, Harrisburg-New York: Morehouse Publishing, 1998, 2nd edition.

Kitab-ı Mukaddes Eski ve Yeni Ahit, İstanbul: Kitabı Mukaddes Şirketi, 1995.

Koç, Mustafa, "Ruh Sağlığı ile Dinî Başa Çıkma Metodu Olarak Dua ve İbadet Fenomeni Arasındaki İlişki Üzerine Psikolojik Bir Yaklaşım”, EKEV Akademik Dergisi, 2005, IX, sy. 24, s. 11-32.

-----, “Dua ve İbadetin Ergenlerin Ruh Sağlıklarına Etkileri Üzerine Teorik Bir Yaklaşım”, Diyanet İlmi Dergi, 2005, XLI, sy. 4, s. 63-90.

Krucoff-Crater: Mitchell W. Krucoff and Suzanne W. Crater, "What Do 'We' Want and Need to Know About Prayer and Healing?", The Journal Of Alternative And Complementary Medicine, 2009, XV, sy. 12, s. 1259-1261.

Kwiatkowski-v.dgr.: Kate Kwiatkowski, Robert M. Arnold, David barnard, "Physicians and Prayer Requests", Journal of Palliative Medicine, 2011, XIV, sy. 11, s. 1259-1260.

Leibovici, Leonard, "Effects of Remote, Retroactive Intercessory Prayer on Outcomes in Patients with Blood-stream-infection: Randomised Controlled Trial”, British Medical Journal, 2001, CCCXXIII, sy. 7327, s. 1450-1452.

Levine, Murray, "Prayer as Coping: A Psychological Analysis", Journal of Health Care Chaplaincy, 2008, XV, sy. 2, s. 80-98.

Masters-v.dgr.: Kevin S. Masters, Glen I. Spielmans, Jason T. Goodson, "Are There Demonstrable Effects of Distant Intercessory Prayer? A Meta-Analytic Review", Annuals of Behavioral Science, 2006, XXXII, sy. 1 s. $21-26$.

Matthews-v.dgr.: Dale A. Matthews, Sally M. Marlowe, Francis S. MacNutt, "Effects of Intercessory Prayer on Patients with Rheumatoid Artritis", Southern Medical Journal, 2000, XCIII, sy. 12, s. 1177-1186.

Mehmedoğlu, Ali Ulvi, Tanrıyı Tasavvur Etmek, İstanbul: Çamlıca Yayınları, 2011.

Morgan, Oliver J., "Pastoral Counselling and Petitionary Praying", Journal of Religion and Health, 1987, XXVI, sy. 2, s. 149-152.

Pınar, Zehra, Duanın Ruh Sağlığı Üzerindeki Etkileri (yüksek lisans tezi, 2013) Erciyes Üniversitesi SBE.

Ross, Alastair, Counselling Skills for Church and Faith Community Workers, Maidenhead-Philadelphia: Open University Press, 2003.

Ross-vdgr.: Louie E. Ross, Ingrid J. Hall, Temeika L. Fairley, Yhenneko J. Taylor ve Daniel L. Howard, "Prayer and Self-Reported Health Among Cancer Survivors in the United States, National Health Interview Survey, 2002", The Journal Of Alternative And Complementary Medicine, 2008, XIV, sy. 8, s. 931-938. 
Sayın, Esma, “Tasavvuf ve Psikoloji Açısından Duanın Terapik Etkileri”, Batman University Journal of Life Sciences, 2012, I, sy. 1, s. 423-431.

Silton-v.dgr.: Nava R. Silton, Kevin J. Flannelly, Kathleen Galek, David Fleenor, "Pray Tell: The Who, What, Why, and How of Prayer Across Multiple Faiths", Pastoral Psychology, 2013, LXII, sy. 1, s. 41-52.

Simão-v.dgr.: Talita Prado Simão, Sílvia Caldeira and Emilia Campos de Carvalho, "The Effect of Prayer on Patients' Health: Systematic Literature Review", Religions, 2016, VII, sy. 11, http://www.mdpi. com/2077-1444/7/1/11/htm (erişim tarihi: 24.05.2017).

Spring, Heather J. Encountering God: A Grounded Theory Of Prayer In Illness (doktora tezi, 2002), Florida Üniversitesi.

Stoner-Murray: M. Stoner and C. Murray, "Say a Little Prayer", Nursing, 1998, XXVIII, sy. 6, s. 55.

Strang, Cecily Walter "Is Intercessory Prayer in Modern Nursing a Valid Practice?", Journal of Christian Nursing, 2011, XXVIII, sy. 2, s. 92-95.

Taylor, Elizabeth Johnston, "Prayer's Clinical Issues and Implications", Holistic Nurings Practice, 2003, XVII, sy. 4, s. 179-188.

VandeCreek, Larry, "Exploring Intercessory Prayer”, Journal of Health Care Chaplaincy, 1998, VII, sy. 1-2, s. 1-6.

VandeCreek, Larry, "Mahalle Papazlarının Hastanede Yatan Kilise Üyelerine Yönelik Dua Vaizliği” (trc. Ali Rıza Aydın), Din Bilimleri Akademik Araştırma Dergisi, 2003, III, sy. 1, s. 153-167.

Welker, Maureen, Review of The Literature on Effects of Prayer on Patient Outcomes (yüksek lisans tezi, 2001), Department of Nursing California State University.

Williamson, W. Paul, "Review of Varieties of Prayer: A Survey Report" (authors: M. M. Poloma ve G. H. Gallup, Jr., Philadelphia: Trinity Press International. 1991), The International Journal for the Psychology of Religion, 1994, IV, sy. 3, s. 203-204.

Whittington-Scher: Brandon L. Whittington and Steven J. Scher, "Prayer and Subjective Well-Being: An Examination of Six Different Types of Prayer", The International Journal for the Psychology of Religion, 2010, XX, sy. 1, s. 59-68.

Winslow-Winslow: Gerald R. Winslow and Betty Wehtje Winslow, "Examining the Ethics of Praying With Patients", Holistic Nursing Practice, 2003, XVII, sy. 4, s. 170-177. 